Louisiana State University

LSU Digital Commons

1986

\title{
An Exploration of the Type a Behavior Pattern in Chronic Headache Sufferers.
}

Neil Bruce Rappaport

Louisiana State University and Agricultural \& Mechanical College

Follow this and additional works at: https://digitalcommons.Isu.edu/gradschool_disstheses

\section{Recommended Citation}

Rappaport, Neil Bruce, "An Exploration of the Type a Behavior Pattern in Chronic Headache Sufferers." (1986). LSU Historical Dissertations and Theses. 4321.

https://digitalcommons.Isu.edu/gradschool_disstheses/4321

This Dissertation is brought to you for free and open access by the Graduate School at LSU Digital Commons. It has been accepted for inclusion in LSU Historical Dissertations and Theses by an authorized administrator of LSU Digital Commons. For more information, please contact gradetd@lsu.edu. 


\section{INFORMATION TO USERS}

While the most advanced technology has been used to photograph and reproduce this manuscript, the quality of the reproduction is heavily dependent upon the quality of the material submitted. For example:

- Manuscript pages may have indistinct print. In such cases, the best available copy has been filmed.

- Manuscripts may not always be complete. In such cases, a note will indicate that it is not possible to obtain missing pages.

- Copyrighted material may have been removed from the manuscript. In such cases, a note will indicate the deletion.

Oversize materials (e.g., maps, drawings, and charts) are photographed by sectioning the original, beginning at the upper left-hand corner and continuing from left to right in equal sections with small overlaps. Each oversize page is also filmed as one exposure and is available, for an additional charge, as a standard $35 \mathrm{~mm}$ slide or as a 17 "x 23 " black and white photographic print.

Most photographs reproduce acceptably on positive microfilm or microfiche but lack the clarity on xerographic copies made from the microfilm. For an additional charge, $35 \mathrm{~mm}$ slides of 6"x 9" black and white photographic prints are available for any photographs or illustrations that cannot be reproduced satisfactorily by xerography. 


\title{
8710585
}

Rappaport, Nell Bruce

AN EXPLORATION OF THE TYPE A BEHAVIOR PATTERN IN CHRONIC HEADACHE SUFFERERS

$\begin{array}{lll}\text { The Louisiana State University and Agricultural and Mechanical Col. } & \text { PH.D. } \quad 1986\end{array}$

\author{
University \\ Microfilms \\ International 300 N. Zeeb Road, Ann Arbor, MI 48106
}




\section{PLEASE NOTE:}

In all cases this material has been filmed in the best possible way from the available copy. Problems encountered with this document have been identified here with a check mark

1. Glossy photographs or pages

2. Colored illustrations, paper or print

3. Photographs with dark background

4. Illustrations are poor copy

5. Pages with black marks, not original copy

6. Print shows through as there is text on both sides of page

7. Indistinct, broken or small print on several pages

8. Print exceeds margin requirements

9. Tightly bound copy with print lost in spine

10. Computer printout pages with indistinct print

11. Page(s) author. lacking when material received, and not available from school or

12. Page(s) seem to be missing in numbering only as text follows.

13. Two pages numbered . Text follows.

14. Curling and wrinkled pages

15. Dissertation contains pages with print at a slant, filmed as received

16. Other

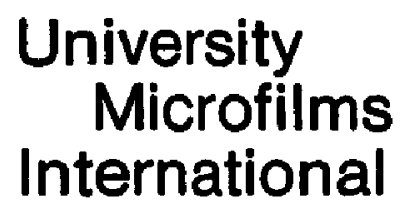




\title{
AN EXPLORATION OF THE TYPE A BEHAVIOR PATTERN
}

IN CHRONIC HEADACHE SUPEERERS

\author{
A disertation \\ Submitted to the Graduate Faculty of the \\ Louisians state University and \\ Agricultural and Mechanical Colleme \\ in partial fulfillment of the \\ requirementa for the degree of \\ Doctor of Philosophy \\ In \\ The Department of Peychology
}

by

Ne11 B. Rappaport

B.A. San Diego State Untversity, 1978

M.A. Loulsiana State University, 1984

December, 1986 


\title{
Acknowledgementa
}

\section{"White. A blank page or canvas.} H1. favorite. So many poselb1lities..."

(Sondhe1m, 1984)

\author{
One faces a multitude of blank pages during a \\ graduate school career. Just how these Innumerable \\ pases became filled with words and ldeas ls st1ll a \\ mystery to me. As well, how this project elnaliy \\ reached fruition is a wonder. One thing of which $I$ am \\ certain is that it took the asalatance and support of \\ many people. I would like to take thls opportunity to \\ formally expresa my aratitude to the people who made \\ significant contributions to the completion of this \\ Btudy. \\ First to the members of my disiertation committee: \\ Drs. Ray Buss, Mary Lou Kelley. Arthur Rlopelle, and \\ W11l1am waters. In many ways you taught me more about \\ research and scientific Investigation through this \\ single experience than most other academic activities. \\ I thank you all for providing me with such excellent \\ role models. \\ Special thanks to my sraduate school advisor and \\ Priend. Phili1p J. Brantley, who provided me with a \\ rich and full education. And who; for the first time \\ In our relationghip, earned more tokens than I did.
}


On a more personal level. I would like to thank my family and friende in New York, Californta, Texas. Loulelana, and Mise1esippl, who underetood and withatood the last five yeare. Indeed, I am a very fortunate individual. Speciflcally. I thank Debra, for your strength and loyalty: Anne, for your humor and depth; CJ. for your love and eupport; and sharon, for your Insight and generosity.

I express my deepest eratitude to David Mcanulty. my erlend, colleague, and partner in this research, who provided me with the strength to persevere and gave me the knowledge to understand $11 f e$.

Finaliy. I would like to acknowledge the contributions of my parenta. They've provided love and tolerated theip younger son'a preoccupation with self and hig wandering around the country during the past Ive years. 
An Explopation of the Type A Behavior Pattern In Chronic Headache Sufferers

TABLE OF CONTENTS

\section{TYPE A BEHAVIOR PATTERN}

Historical Perspectivea...................... 1

Description of the Pettern.................... 2

Meseurement of the Pattern.................... 4

structured Interv1ew......................

Jenkins Activity survey..................... 7

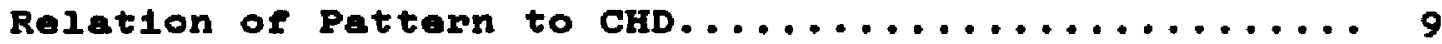

Underlylns Mechanlame of the Pattern............. 13

Paychologlcal Correlates of the Pattern............ 17

Paychopatholozy.......................... 19

Type A Behevior Pattern and stress............ 21

Type A Behavior Pattern and social Functioning.... 23

MEADACHE CLASSIFICATION

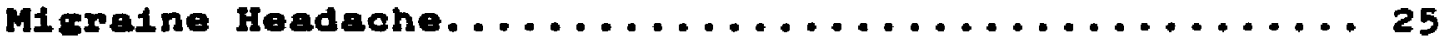

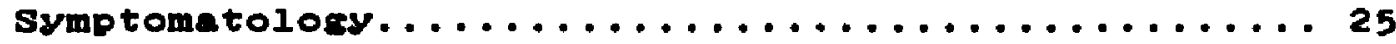

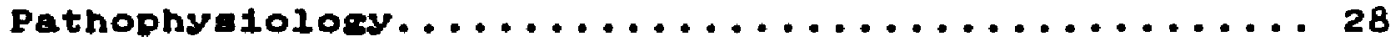

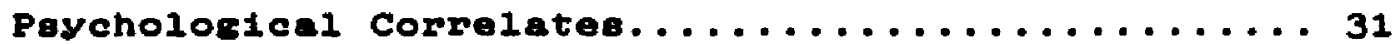

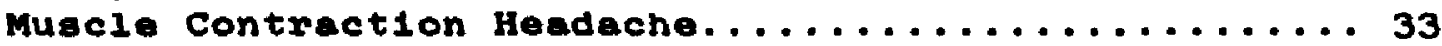

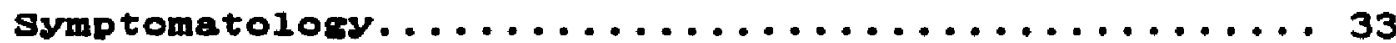

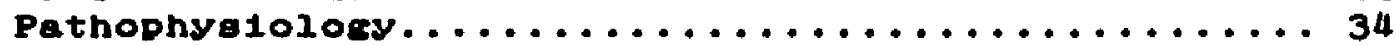

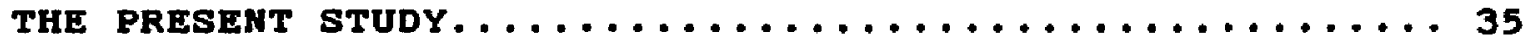

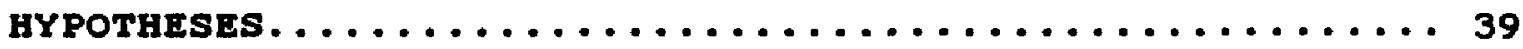

METHOD

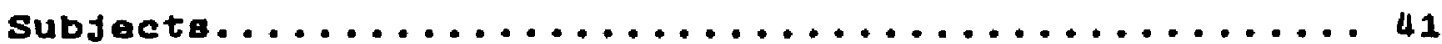

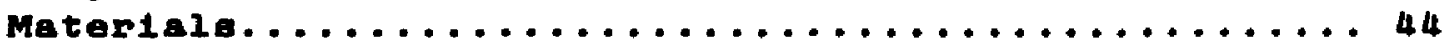

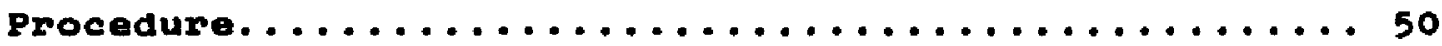

RESULTS ........................................... $\ldots 5$

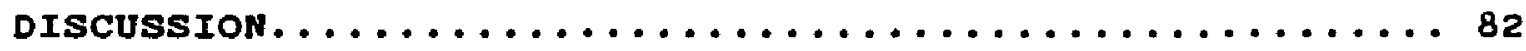

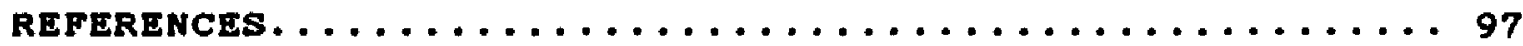

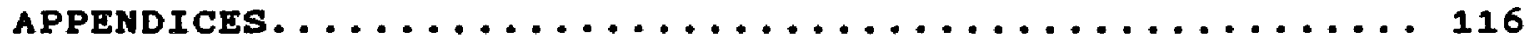

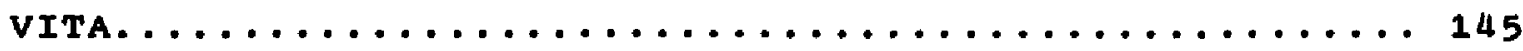


TABP and Headache

\begin{abstract}
Abetract
Recently, Investisations have examined the poselble link between the Type A Behavior Pattern (TABP) and chronic headache. Several etudies have Indicated a elenificant relation between Type A, as measured by the Jenkine Activity survey (JAS), and headache frequency. As well, several researchers have noted the elmilarities in the descriptions of the Type A Individual and those characteristics of the "migraine personality." To date, no prospective etudy has examined whether that set of charecterlotics ascribed to migraineurs 18 in fact the TABP. The second focus of thia investigation was to provide a comprehengive description of the psychologlcal functioning of Type A and B headache aufferers across several domalns: psychopathology, social functioning, health beliefa and beheviors. and daily stress monitoring. S1xty chronte headache suffererg ( 30 tension. 30 misraine) volunteered as gubjects for this Investigation. Participants provided full headache n1storles and were dlagnoaed by both a doctoral candidate in clinical paychology and a neurologist according to Ad Hoc Committee criterla. All participants kept headache diarles for elght weeks and
\end{abstract}


TABP and Headache

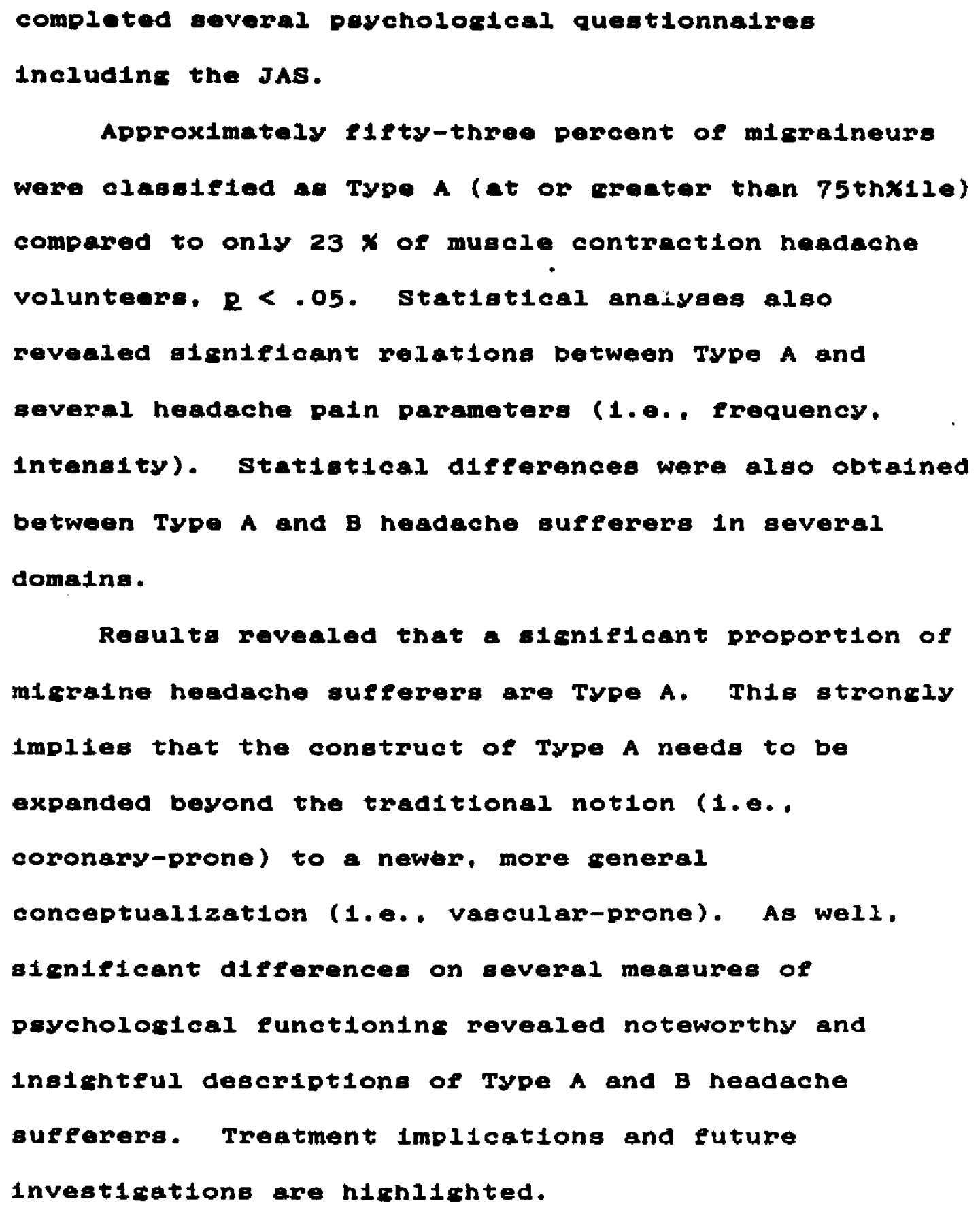


TABF and Headache

An Exploration of the Type A Behavior Pattern

In Chrontc Headache Suffererg

\section{Historical Perspectives of the TABP}

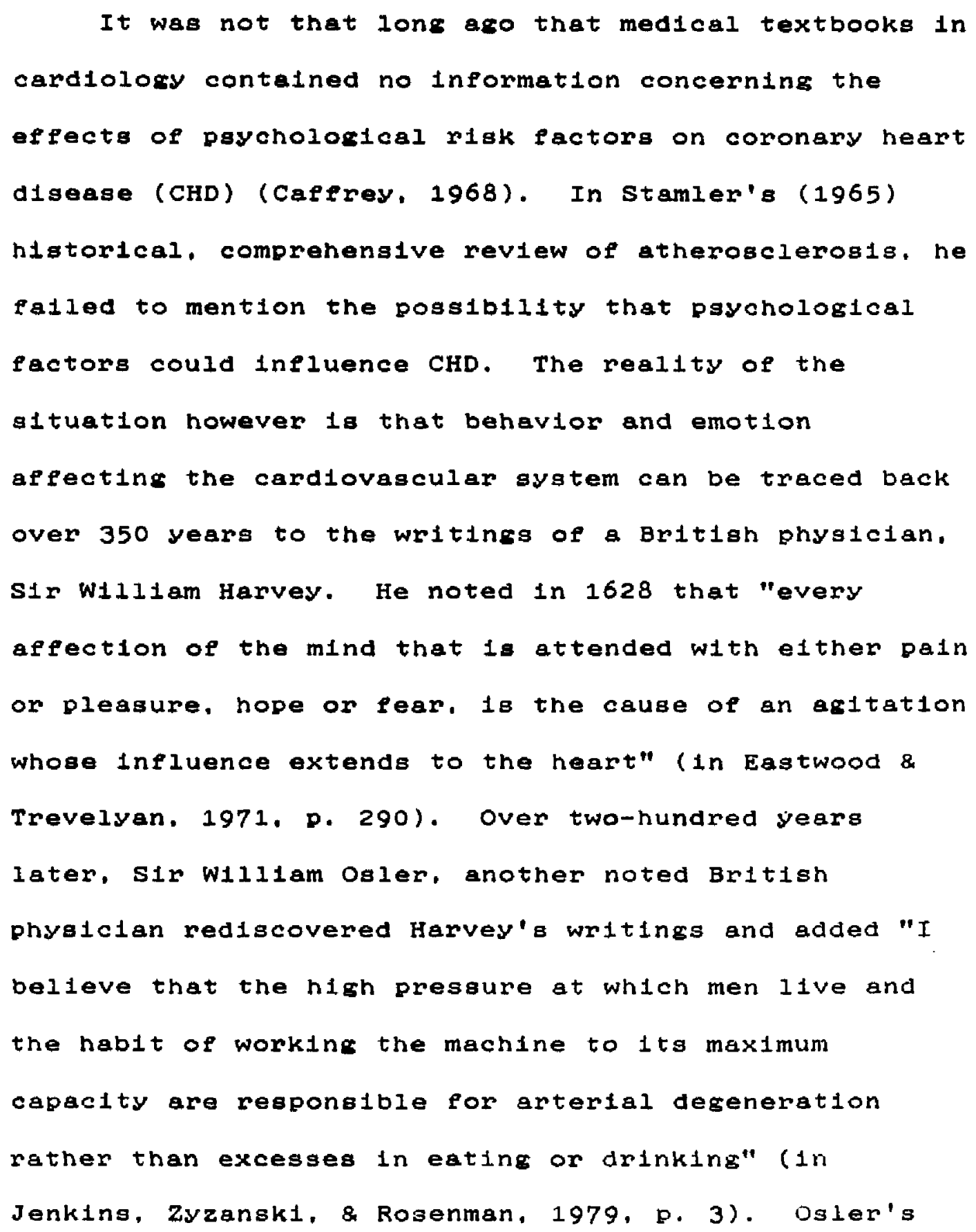


description of "the coronery-prone" patient would remaln an esoteric one until the Menningers (1936) adopted this position, bringing the notion of coronary-prone behavior to the United Stater. The modern notion of the coronary-prone behavior pattern--also called Tyue A--1s an epldemiological construct that arose from Friedman and Rosenman's (1974) observations of the behavior of cardiac patients In their private prectice during the 1950's. Compared with the noncardiac patients thes were treating. middle-aged and younger patients suffering from cardiac disorders seemed to possess a noteworthy constellation of behavioral characterlstics (Matthews, 1982).

Disappolnted by the fallure of traditional risk factors for heart disease (e.g. hypertension, smoking, obesity, etc.) to predict half of the new cases of clinical coronary heart disease (Jenkins, 1976), they turned their attention to systematically observing that collection of behaviors that subsequently was termed the Type A behavior pattern (TABP). Description of the Pattern Cardiologists Frledman and Rosenman were chlefly responsible for the earliest descriptions and development of the TABP. In extreme manisfestations. the pattern represents "a tightly woven tapestry of habits, goals. characteristic modes of striving and 
achievement motivation, and pergonality tralta" (Sparacino, 1979, p. 38). Individuals displaying this pattern are usually overtiy competitive, agressive or even host1le (Glasa, 1977; Manuck \& Garland, 1979; Nowack \& Sessenrath, 1980), exceedingly demanding of self and other, and chronically restless, impatient. and time consclous (Manuck, Craft, \& Gold, 1978; Loval10 \& Plshk1n, 1980: Carver \& Glass. 1978; Irvine \& Allen, 1982). According to Frledman (1969), the Type A behavior pattern refers to

"a characteristic action-emotion complex which $1 g$ exhiblted by those Individuals who are engaged In a relatively chronic struggle to obtain an unlimited number of poorly defined things from their environment in the shortest period of time and, If necessars, against the opposing efforts of other thines or pergons in the same environment" (P. 84$)$.

Jenkins (1976) further observes that the TABP represents nelther "a stressful situation nor a distressed response, but rather a style of behavior with which some persons habitually respond to circumstances that arouse them (p. 1034)." The overt manffestations of Type A Individual's struggle include explosive, accelerated speech, a nelghtened pace of Ilving, impatience with slowness, concentrating on more 
than one activity at a time, self-preoccupation, dissatisfaction with 11fe, evaluation of the worthiness of one's activities in terms of numbers, a tendency to challenge and compete with others even in noncompetitive situations, and free-floating nostility (Matthews, 1982; Matthews \& Haynes, 1986). The major faceta or "core" elements of the TABP are extremes of aggressiveness, easily aroused hostlifty, a sense of time ursency, and competitive achlevement striving (Rosenman, 1978). The extent to wh1ch Type A represents a "tralt" depends on one's underlying model of a trait. Strictiy speaking, the TABP 1s not considered to be a tralt. Rather, it 1s a set of "overt behaviors that is elicited from susceptible Individuals by an appropriately challenging environment" (Matthews, 1982, p. 293). Addttionally. the TABP 1s not to be consldered a discrete typology. Rather, 1t 1s hypothesized to be a continuum of behaviors ranging from extreme Type A to extreme non-Type A or Type B. This notion will be discussed in more detall later.

Measurement of the Type A Behavior Pattern

Structured Interview. As noted before. the initial formulation of the coronary-prone behavior pattern was based on the clinical experience of Friedman and Rosenman. Recognizing the need for Improved 
specification of the criteria for measuring the behavior pattern. these cardiologista developed a measure based on a structured interview (SI) (Rosenman, et al. 1964). The SI was designed to provide a sultable chellenge to elicit the TABP in predigposed individuals. The SI requires about 15 minutes to administer and $1 \mathrm{~s}$ audiotaped or videotaped for subsequent scorins. Both Interviewers and reters imut be trained to provide a standardized. valid assessment. Rating of the SI takes Into account stylistics of speech (1.e.. the way something 18 said by the Interviewee). the content of the answers (1.e.. what is said), and overt psychomotor, nonverbal behaviors exhlblted in the Interview. Although all three factors are taken into account in the gcoring, the content and nonverbal behavtors are welghed less heavily, because Type As often have little insight into their own behavior (Rosenman, 1978). Instead. emphasis 1s placed on the speech stylistics. The value of the stylistics for assessment of coronary-prone behavior has been conflrmed (Schucker \& Jacobs, 1977). Methodolog10al studieg of the SI have shown high levelg of Interrater reliability (Caffrey, 1968) and stability over time (Jenkins, Rosenman, \& Friedman, 1968).

Type As who have been ldentifled through the use of the SI have been ghown to be at higher risk for CHD 
Incldence regardless of other risk factors (Brand. Rosenman, Sholtz, \& Friedman, 1976; Frledman \& Rosenman, 1959; Jenkins, 1971; Jenkins, 1976; Rosenman et al.. 1975). Th1s 18 also holds when attempting to predict the severity of atherosclerosis, the underlying coronary process (Blumenthal, Wliliams, Kong. Schanbers, \& Thompson, 1978; Friedman et al., 1968; Dembrosk1, MacDougal1, W1Illams, Haney, \& Blumenthal, 1985; Zyzansk1, Jenk1ns, Ryan, Flessas, \& Everist, 1976). It seems 11 kely that the behavior pattern $1 \mathrm{~s}$ quite gtable for most individuals over time. In gubjects in the Western Collaborative Group study (WCGS) and other similar smaller scale Investigations, 75-80\% showed a similar categorlcal assessment by the SI method over a period of 12 to 20 months (Jenkins, Rosenmen, \& Frledman, 1965; Kelth, Lown, \& Stare, 1965).

The SI $1 \mathrm{~s}$ not an Ideal measure becauge it $1 \mathrm{~g}$ an emplrical instrument that is not truly objective and does not provide numerical quantiflcation. Moreover. as noted above, It requires a perlod of training for its effective administration and assessment. On a practical level as well. It requires much time and expense. In an effort to overcome some of these shortcomings, attempts have been made to develop a guestionnalre which has the ability to ldentify 
Individuals demonstrating the behavior pattern. The Jenkine Activity Survey (JAS) was developed to duplicate the clinical assessment of the TABP by a more standard psychometric procedure and to make Type A asgesgment more accessible for researchers.

Jenk1ns Act1v1ty Survey. The best-studied, most widely accepted paper and pencil measure of the TABP is the Jenkins Activity Survey (Jenkins, zyzanski, \& Rosenman, 1979) which has been avallable in several forms since 1964 for research and clinical use with different populations. The JAS was constructed over an 8-year perlod; four earlier editions were avallable previous to the current Form $C$ (for use with employed adults) which was published and copyrighted by Jenkins et al. (1979). Items for the JAS were derlved from the SI as well ag from Jenkin's obgervations of Interview behavior and the theory of Type A behavior. The earlier forms of the JAS were administered to males who had also been rated on the SI. The 40 1tems that correlated best with the ratings of the SI were kept and additional new 1tems were developed. Discriminant function analsses were used at each stage of development to select 1tems that might best differentlate between independentiy assessed Type $A$ and Type B 1ndividuals. Form C contalns the 52 items that best discriminated between the two groups. 
The TABP eg asgessed by the JAS fs gignificantly related to CHD prevalence In many populations. JAS scores for TABP were predictive of new cases of CHD (Jenkins, Rosenman, and Zyzanskt, 1974), risk of reinfarction in the WCGS (Jenkins, Zyzansk1, Rosenman, \& Cleveland, 1971; Jenkins, et al., 1976), and degree of basic coronary atherosclerosis in some (zyzanski et al.. 1976), If not all (Blumenthai. et al.. 1978). gtudies. (Several pesearcherg have noted that the Blumenthal et al. (1978) study included many persong with demographic characteristics that were substantialy different from the population for which the JAS was developed and standardized.) Generally. findings from a vast literature suggest that. compared to the SI. the JAS 18 a somewhat weaker predictor of CHD Incidence (Brand, et al.. 1976) and of the physiological arousal, which is thought to be the underlying mechanlsm which links the behavior pattern to CHD (MacDougall, Dembrosk1, \& Musante, 1979). The relative strength of the SI compared to that of the JAS, and other questionnalres that proport to measure the TABP, may be that the interview is based more on direct observation of the behavior pattern than upon the content of answers to questions. On balance, while the JAS $1 \mathrm{~s}$ somewhat Inferior to the SI when attempting to predict CHD prevalence, 1t's use in the TABP 
research literature 18 widegpread. "In spite of the Instrument's limitations, research does support 1ts utility. It can evaluate broad sroup differences and provide clinical Investigators with a means of assegsing an Important construct in proneness to CHD" (Green, 1982, 0.356). Reletion of TABP to CHD

A significant relation of the TABP with CHD prevalence has been found In both sexes that could not be attributed to differences of diet or any other traditional rigk fectors (Friedman \& Rosenman, 1959; Rosenman \& Friedman. 1961). Many other studies have confirmed these first investigations (for reviews see Feinlelb, Brand, Remington \& Zyzansk1, 1978; Rosenman \& Chesney, 1980). These conflrmations proved to be ofanficant whether the pattern was measured by elther the SI, or the JAS (Jenking, Rogenmen, \& Zyzanski, 1979). Or other measures (Bortner. 1979; Kannel \& Gordon, 1974; Thurstone, 1949).

Differences of TABP may in part explatn considerably higher CHD rates in the densely populated, Industrialized regions of the United States and England (S1gler, 1959) compared to the farm belt, where consumption of anlmal and dalry fat is higher. Such differences probably also help to explain higher rates In the United States compared to Europe (Keys et al.. 
1972) and in the Framingham invegtigation's males comparad to those in Yusoslavia (Kozarevic. Plre. Ravic, Dawber, Gordon, \& Zukel, 1976), Puerto Rico and Hawal1 Gordon, Garcla-Palme1ri, Kagan, Kannel, \& Schiffman, 1974), and Parle (Ducimetiere, Cambien, RIchard, Rakotovao, \& Claude, 1980).

The association between TABP and CHD has recelved mafor conflrmation in prospective research as well. The Western Collaborative Group Study was a prospective epidemiological Investigation of over three-thousand healthy males, aged 39-59 sears at intake in 1960-1961, who were employed by 10 California companies (Rosenman et al., 1964). Participants were comprenensively studied for all traditional health risk factors. The most detalled descriptions of the population and methodology can be found in Rosenman et al. (1964), as well as the findings at follow-up (Rosenman. Brand, Jenkins, Frledman, Strauss, \& Wurm, 1975: Rosenman. Brand, Sholtz, Friedman, 1976).

The 8.5 year follow-up found CHD in 257 men. Final results showed that men classified as Type A at Intake were 2.37 times as 11kely to develop CHD over the follow-up perlod as were Type B Individuals (Rosenman et al., 1975). Th1s relation was later statistically adjusted to reflect the impact for other risk factors and the relative Type $A / B$ risk of CHD was 
reduced to 1.97 . The signiflcant adjusted flgure. 1.97, represented the relative risk for TABP that was Independent of other rigk factors. These findings Indicate a synergistic pattern for CHD risk in which the TABP operates with nearly constant multiplicative effect applied to whatever background level results from other risk factors. Both of the observed associations, adjusted and non-adjusted risk ratios were statistically alaniflcant, $P<.001$, and therefore could not be attributed to chance fluctuations: these results were also quite comparable to the findings of the later Framingham Investigation (Haynes, Feinlelb, \& Kanne1, 1980).

The Framingham Study (Kannel \& Gordon, 1974)

ylelded a multivariate risk equation for CHD prediction based on standard risk factors. The predicted risk levelg in the Framingham data correlated highly with those obtained in the wCGs. The findings demonstrated a direct association between CHD Incldence and the TABP of an approximate risk ratio of $1.9, p<.0006$, and 2.1. $\mathrm{p}<.002$, for Type A to Type B males, aged 39-40 and 50-59 years, respectively. Thus, substantial risk $1 s$ associated directly to the pattern and does not diminish as Individuals become older. . In the WCGS the association of TABP with CHD Incldence prevalled for Inttial myocardial infarction 
(MI), whether symptomatic or not, as well as for ansina pectorls (Rosenman et al.. 1975). Although significant CHD Incidence occurred in Type A men even at low risk factor levels. Type B Individuals at similar levels exhibited relative CHD Immunity (Rosenman. Friedman. Jenkins, Straus, Wurm, \& Kositehek, 1966). The TABP also was strongly essoclated with recurring and fatal CHD events (Jenking et al.. 1976; Rogenmen et al.. $1966)$.

Subsequent Investigations have confirmed the relation between the coronary-prone behavior pattern and CHD Incidence. As part of the study of CHD among Japanese men In Japan, Hawal1, and Calffornia, over two thousand males completed the JAS In 1967-1968 (Cohen. Syme, Jenkins, Dagan, \& Zyzansk1. 1975). Among the most interesting findings of this investigation were (a) Japanese men in Hawall who were classifled as having undergone cultural change were more prone to CHD and (b) those Individuals who were both culturaliy moblle and Tupe A had two to three times the CHD risk at follow-up (Brand, 1978). These results support the Initial TABP construct as being an interplay between specific behaviors and an environment that challenges the susceptible individual.

Major conflrmation of the relation between CHD and the coronary-prone individual was obtained in the 
follow-up to the Framingham Study (Haynes, Felnlaib. Levine, Scotch, \& Kannel, 1978). A cohort of nearly 2.000 1nd1viduals was adminlstered an extensive questionnalre in 1965-1967 that provided measures of behavior, situational stress, soclocultural mob111ty, and somatto strain. Among these psychometric Ingtruments, the Framingham Type A Scale, was glonificantly related with CHD prevalence in both sexes. even after controliling for other risk factors. Subjects aged $40-74$ and eree of CHD $(\underline{n}=1674)$ were then followed for an additional 8 yeara. During this follow-up period. Type A males were found to be over twlce as likely as Type. Bs to develop anglna and suffer MIs. With stronger asgociations in white- than in blue-collar workers (Haynes, Feinlelb, \& Kannel, 1980). These associations were still glgnifleant when statistically adjusted in order to control for other risk factors. In fact, the respective incidence of engina and MI was 3.32 and 2.14 higher in Type A men than Type B women.

\section{Mechanlsms Underlying the TABP and CHD}

As previously noted, the TABP has been found to be assoclated not only with an increased Incidence of acute CHD clinical events (MI and sudden death) but also with increased levels of the underlying pathological process, coronery atherogclerosis. These 
TABP and Headache 14

\begin{abstract}
associations suggest the existence of mechanlsms that link psychobehavioral processes, most likely vie central nervous system mediation. with those processes Involved in the formation of the atherosclerotic plaque. Extensive laboratory, clinfcal, and epidemiological evidence sugsestg thet such mechanisms Involve (a) hormonal and lipld responses, and (b) physlological responses, both associated with varying behavioral states.
\end{abstract}

A number of studies by Friedman, Rosenman, and their co-workers have shown that extreme Type A persons exhiblt exaggerated hormonal and lipid responses to varlous paychological and behavioral challenges. Type A Individuala have generaliy been found to have higher levels of serum cholesterol then thelp Type B counterparta, both prior to the emergence of cilnically evident CHD (Friedman, Byers, Rosenman, \& Elevitch, 1970) and after the clinical stage is reached (Blumenthal et al.. 1978). With regard to sympathetic nervous system function. Type A subjects have been found both to excrete Increased amounts of norepinephrine during a typical work day (Friedman, St. George, \& Byers, 1960) and to show elevated serum noreplnephrine levels during a challenglng competitive task (Frledman, Byers, D1ament, \& Rosenman, 1975). 
There 1 a how a rapidly srowing body of research Prom several laboratories concerned with ldentifyins differences in paychophygiological respongeg between Type $A$ and Type $B$ Individuals. This research $1 \mathrm{~s}$ the logical extension of the earlier work with regard to enhanced excretion or secretion of catecholamineg among Type A persons. If 1 t was reliably demonstrated that Type A Individuals exhibited excessive sympathetic arousal In response to apeciflc challenge, an Important gtep w111 have been taken toward defining the mechanisms through which behavior plays a role in the pathogentc process in CHD (W1lliams, Friedman, Giass. Herd, \& Schnelderman, 1978).

Dembrosk1. MacDougall, Sh1elds, Petitto, and Lushene (1978) gtudied the physiological response of 50 Type A and Type B Bubjects who were challenged to respond rapidiy and accurately on three tasks involving elther perceptual-motor or cognit1ve ski11s. In general, It was found that Type A gubjects showed sionfelcantly greater cardiovagcular changes indicative of sympethetic nervous system arousal than did Type B subjects. In addition. It was found that increased levels of hostility or competitiveness during the $S I$ were predictive of helghtened phystolglc responses. during the tasks. Uaing a similar set of challenging tasks. Manuck. Craft, and Gold (1978) found Type A 
males to ghow sreater gystolic blood pressure elevations durins task performance in comparison to Type B participanta.

In an extension of earlier work. Dembrosk1. MecDougall, Herd, and ShIeldg (1978) gubjected Type A and $B$ perticipents to the cold pressor test and a reaction time teat under conditions of both high and low challenge. They found that Type A gubjects were more physiolorically responalve overall, though this effect was mogt pronounced under high-challenge conditions. When the subjects were re-classifled with regard to level of hostility and competitiveness, it was found that, In contrast to Type B Individuals, Type As who also displayed competitiveness and hostility were hyperresponsive to both low- and high-challenge Instructions during both tasks. In addition to the differential effect of hostility and competitiveness on the phystological responses of Type A as compared to Type B subjects demonstreted in this study, Scherwitz, Berton. and Leventhal (1978) found that high levelg of gelf-involvement (measured as the simple frequency of use of personel pronouns during the gtructured Interview) were related to eleveted levels of cardiovagcular responses across a wide vartety of experimental tasks amons Type A but not Type $B$ aubjects. 
In addition to these empirical gtudies, it has been proposed (W1lliams, 1975) that both alpha-adrenersically mediated vasoconatrictor responses during sensory intake, or vigliance behaviors and beta-adrenergically mediated cardlac output responses durlng mental work or emergency situations, are two potent1al mechanlams whereby physlologlcal responding durlng qualitatively different behavioral states contribute both to the atherosclerotic process and to the precipitation of acute clinical events. Ongoing studies have recently produced evidence whlch supporta this hypothesis. Whether the behavior pattern 18 assessed by the SI or JAS. Type A male undergraduates show a signtelcantly larger increase in forearm blood flow and a larger increase in plasma epinephrine and cortigol than do Type Ba during a challenging mental arithmet1c task (W1lliams, 1975). Psycholorical Correlates of the TABP

There are a number of reasons why the psychologlcal correlates (1.e.) those paychologlcal constructs such as anxiety, assertiveness, hostility, 1ntroversion. locus of control, etc.) of the TABP are Important to 1nvestigate. From an epidemfological perspective, It is 1mportant to ascertain in a precise manner those components of the TABP which are chlefly responsible for the detrimental effects of the pattern. 
Research has demonstrated that not all those Individuals Identified as Type A develop CHD or any other of the other related cardlovagcular disorders (Eysenck \& Fulker. 1983). Secondly, from a treatment point of view. 1t is important to be able to describe the paychological funotioning of Type As and Bs. If the way Type As behave 1s detrimental to their health, 1t 1 s crucial that we determine before treatment. what In fact it is we are attempting to alter. Describing how Type Ag differ from Type Bs is of utmost importance In order to accomplish this task. Whether we take ancry, hostile, unassertive $A B$ and make them Bs or non-angry, non-hostile, assertive Type As $1 s$ still an unanswered question. Unfortunately. the guality of research in this area of TABP is certalnly the poorest. It Is unfortunate that the Type $A / B$ diatinction has previously tended to develop in fsolation from mainstream poychological research. What will follow 1 s a review of the research Investigating the paychological correlates of the TABP.

The developers of the Type A concept have emphasized that the behavior pattern ig not a reflection of stress, enxiety. or any other paychological disturbance (Jenkins et al. 1979). Recent reviews have noted that there is a need for a more comprehengive view of the TABP than exists today 
(Eysenk \& Fulker, 1983: Matthews, 1982). There 18 a need for 1 t to be related to other, well-established constructs, and. for It to be related to modern. theorles of paychology (Gllbert \& Reynolds, 1984). Studies to date that have evaluated the relation of the construct to well-established personality measures have generally been limited in number and weak in design. For example, Irvine, Lyle, and Allon (1982) found signiflcant correlations between Eysenck's measure of neuroticiam and both the Type $A$ and speed-Impatience scales of the JAS in a small sample $(\underline{n}=37)$. Eysenck and Fulker (1983) found both the Extraversion and Neuroticism factors of the Eysenck Personality Questionnalre to correlate significanty with another unvalidated measure of the TABP. Lovallo and PIshkin (1980) found Type As categorized by the SI to be higher In neuroticism than Bs.

\section{Paychopethology}

A small controvergy within the Type A literature began when Irvine et al. (1982) published their results. They concluded that Type A was psychopathology. This conclusion provoked many researcherg in the fleld to attempt to replicate Irvine et al.'s (1982) results (or rather, attempt to pall to replicate thelp resulta!). Chesney. Black, Chadwlok and Rosenman's (1981) results a year earlier reached 
Just the opposite conclusions. Chesney et al. (1981) found no differences between Type As and Bs ( $\underline{n}=384$ ) on neuroticism, anxiety (STAI), and depression and - sometization acales of the SCL-90R. These authors concluded that "there 18 little relationghip between the TABP and 'paychological distress'" (Chesney et al.. 1981, p. 225). Wadden, Anderton, Foster, and Love (1983) attempted to study these same relations. They explored the relation between the JAs scales and psychopathology as measured by the MMPI. Results Indleated that the JAS Type A sale did not correlate gigntflcantly with the MMPI "neurotic" scales. The Type A scale however did correlate eleniflcantly with other MMPI scales, but all the correlationg were negative, demonstrating an inverse relation between Type A behavior and paychopathology (Wadden et al.. 1983). Unfortunately. the subjects in this study were a "mlxed lot:" they were recruited from varlous hospltal elintcs, with some patients diagnosed with essential hypertension and varlous other cardiac-related risk factors, none of which were controlled experimentally nor statistically. Still. these findings were in direct opposition to the claims of Jenkins et al. (1979) who still claimed that the TABP was unrelated to psychological disturbance. 
Although the sample size in the chesney et al. (1981) Btudy was certainiy adequate, the population repreaented 18 certalnly questionable; subjecto were employed males without any known history of CHD or any other cardiovascular disorder. This implies that while these aubjects might have been clasalfied as Type A. they probably were not truly representative of a clinical gample of Type As. 1.e.. gubjecta 1dentified as having some cardiovascular dyseunction. This 1a the mejor flaw in most of the research in this area. Almost all the studies reviewed, attempting to discover possible correlations (and therefore degcriptions) between the TABP and other paychological concepta heve used non-cilnical. often undergraduate. populations. The seneralizability of these studies lo certalniy questionable. Although Jenkins and his co-workers advocate further Investigations of the paychological correlates of the TABP, to date. no empirical study uBing a clinteal aample of Type As, clasgified by a validated measure of the construct, has Investigated this Important domain.

\section{TABP and Meagures of Stregs and Health Behaviors}

Although the major hypothesis linking the TABP

with CHD and other cardiovascular disorders $1 s$ concerned with excessive gympathetic nepvous system arousal. a gecond hypthosig has gained some attention. 
It ougrestg that Type As fail to percelve phyalcal aymptoms and thus chronically overexpose themselves to stressors (see Hart, 1983 for a comprehensive review of th1s hypothesis). Moreover. Type A Individuals may experience an Inordinate delay In seeking medical care after the onset of cardiac-related aymptoma, which in 1tgelf is a risk factor of CHD (Carver, Coleman, \& Glass, 1976). Laboratory and fleld studies have also extended the notion that Type As fall to report phystcal symptoms (Burke \& Welr, 1980; Hart, 1983; Matthews \& Carra, 1982; Weldner \& Matthews, 1978). To date. no Investigation has attempted to prospectively study differences between Type $A$ and $B$ Individuals as they monitor dally otressors. This 18 due in large part to the lack of a valid Instrument to measure daily stress, but also to the fact that this second hypothes1g 1a generaliy overlooked in the experimental 11 terature.

All of these findings Imply potential differences between Type $A s$ and $B s$ on dimensions of 11lness behavfors. To date however, no emplrical study has examined systematic differences between Type $A$ and $B$ Individuals on rellable measures of iliness behaviors and beliefs. If signiflcant differences exist between these two groups, one could speculate that current 
Intervention strategies for Type A Individuals could benefit from this new treatment component.

\section{TABP and Soc1al Functiontino}

Perhaps the most active research area in TABP Involves the assessment of soclal skills. Researchers have hypothealzed that interpersonal sk1ll defleits amons Type AB may account for the development and malntenence of the hostile style and overtly competitive beliefs and Interactions that characterize the pattern (Watkins, 1986; Watkins \& Elsler, 1986). The mechanlsms by which interpersonal inadequacy affects physical health have becun to be examined. For Instance, some researchers have suggested that soclally unskilled Individuals may fall to develop social support systems. Berkman and Syme (1979) describe a relation between lack of social support. itress symptoms, and early mortal1ty. Cobb (1976) also presents evidence that supportive Interactions protect people from some of the health consequences of stress. Early TABP intervention atudies (Roskies, Kearney. Spevack, Surk1s, Cohen, \& Gilman, 1979: Roskies, Spevack, Surkis, Cohen, \& Gilman, 1978; Sulnn \& Bloom, 1978) were based largely on anxiety reduction models. These studies generally falled to produce any alenificant reduction in the magnitude of the behavior pattern. Consequently, this strategy was dropped. 


\section{TABP and Headache 24}

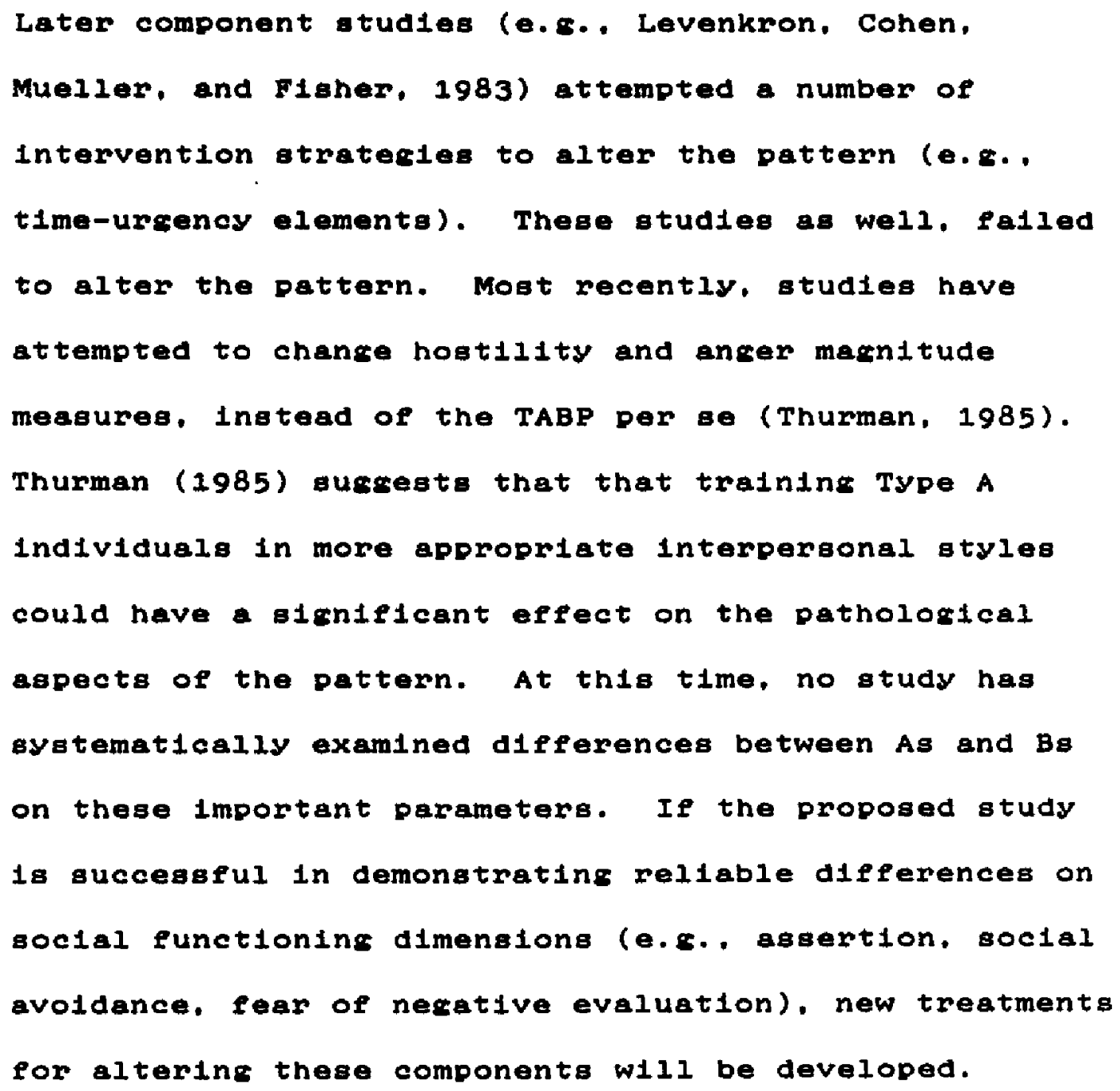




\section{Overviow of Headache cleselfication}

Cec1l'g Textbook of Medicine (Beeson, McDermott, \& Wynsaarden, 1979) notes that the headache 1s the most common of all physical complainta. Andrask, Blanchard, Arena, Saunders, \& Barron (1982) reported that this wideapread paln complaint has the highest prevalence across virtualiy all levels of social class, age, race, education and Intelligence. Approximately ninety percent of all Individuals have reported headache symptoms or problems durlng particular periods In their lives. Adams, Feuersteln, and Fowler (1980) noted that an estimated 42 million Americans guffer from headaches: that number they point out is nearly equivalent to the common cold. The Ad Hoc committee on classification of Headache (1962) established fifteen different catesories of headaches. Which included migraine and muscle contraction headaches, sinus headaches, and a varlety of headaches resulting from organic basea. As noted previously. because almost all Individualg guffer headachea from time to time, there 1s a large gubgroup of the general population classifled as chrontc headache individuals. These Individuals auffer from headaches on a regular basts over months or years. Because behavioral researchers have been involved almost exclusively with the first two syndromes (muscle contraction and migralne), no 
further discussion of other headaches would be appropriate nere.

The 1asue of rellable diagnosis of headache has not yet been settled. That 1s, although a rellable set of diagnostic criteria have not been fully established and accepted by the medical and paychological community, a workable clinically-relevant set of diarnostic criterla were proposed by the Ad Hoc Committee (1962). These criterla have also become the diagnostic criteria used in most scientific Investigationg regarding headaches.

The following diacusaion of the pathophysiology and clinical symptomatology of muscle contraction and migraine headaches 18 almed at providing gufficient information to link the TABP with headache research. In the case of migraine headache, an additional section regarding the personality varlables agsociated with that vascular syndrome hag been included. For pull literature reviews see Adams, Feurstein, and Fowler (1980) for migraine and Andragik et al.(1982) and Williamson (1981) for muscle contraction headaches.

\section{Migraine Headaches}

Symptomatology. The Ad HoC Committee (1962) Identifled five types of vascular headaches: classic and common migralnes, cluster headache, hemiplesic migraine. and lower-half headache. The vast majority 
of vacular headache pettenta are clasalfied as elther claselo or common migratne (W1111amson. 1981) whereas the other types have been rapely invegtigated. Migratne 1 a characterized by gevere, throbbing pain that has a unilateral or one-sided locus at onget. The most common locatione of paln are near the temporal, orbital, auprarbital, or occipltal ragions of the head. For some patients, the pain may remain localized and for othera. 1t may radiate to other areas. The pain usualiy lasts for 4-8 hours, though many Individuala report headache boutg of up to several days. The erequency of headeche has been reported to range erom two or three per week (or more) to less than one per year. Moat migraine patienta report that head pain 1 g often accompanied by naugea and vomiting; $1 t$ should also be noted that often patienta report feeling better followine a vomitlne episode. Other common features of the migratne headache include: anorexia. hypergensitivity to liaht, gound, odors, constipetion or diarnea.

Migralneurs are often further clasifiled as elther common or clasilc. The classic migralne headache gufferer reporta experiencing "warning atenalg" or prodromes before the headache phase. The prodromal glang Include blind gpotg in the visual fleld. flaghing 1ighta. vertigo, parathesias of the face or hands, etc. 
Common migraine has all of the same characteristica except there 1 s not a clearly defined prodromal phase. About $85 \%$ of migraineurs are claseified as common and their pain duration seems to be sightiy loncer ag compared to clasale mioratne sufferero (Adams. Feuergte1n, E Fowler, 1980).

Pathophye10lory. Early paychophysiolog1cal research in this area revealed migraine to be of vascular ortein (Tunia \& Wolff, 1952): extra- and Intra-cranial artery vasoconatriction during the preheadache phase followed by hypervagodilation during the headache attack (Andragik et al.. 1982). Although gome of the aspects of this almple model have not been supported in empirical studies of migraine for various reasons (1e. poor methodologies. equivocal results. poor control eroups. Inadequate descriptions of diacnostic procedures). ectentiats and practitioners alike are atill convinced that the predominent end organ gygtem of the migraine attack lies in the vascular system. That 1a, migraine headache 18 a dysfunction of the cranial vascular beds (Bakal. 1975: o'Brien, 1971).

Graham and Wolfe (1938) were the first to show that the pulations of the temporal artery are Increased during the headache phase of migraines. The1r work was baged on observationg of the effect of 


\begin{abstract}
ercotamine tartrate on extracranial vesiels in the relief of migraine. The ersotamine dimintshed the Increased amplitude of the arterial pulsation, with correspondine ralief of the headache. These results seemed reasonable in view of work with histamine. which had clearly shown that Btretched extracranial arteries are capable of producling paln (Clark, Hough, \& Wolff. 1936). The above discoverles lald the foundation for the vascular theory of migraine.
\end{abstract}

An accident Involving an anglogram with a patient (Dukes \& V1eth, 1964) while having a misraine atteck demongtrated for the flrst time the "biphasic" nature of migraine. In recent years. Investigators have postulated that an agent, or agents. causing vagoconstriction may intiate the headache sequence. s1cuter1 (1967) proposed thet Buch substances as amines. Including epinephrine and norepinephrine, and serotonin--all potent vasoconstrictors--were regpona1ble. Further evidence was found that during the mfaralne attack 1tself, some subjectg secrete Increased amounts of catecholamine end products (S1cuter1. 1967$)$.

Based upon the vascular, blochemical and neurological mechanisms that have been postulated as having some relation to the etiology of migraine. Diamond and Dalesalo (1978) have formulated the 


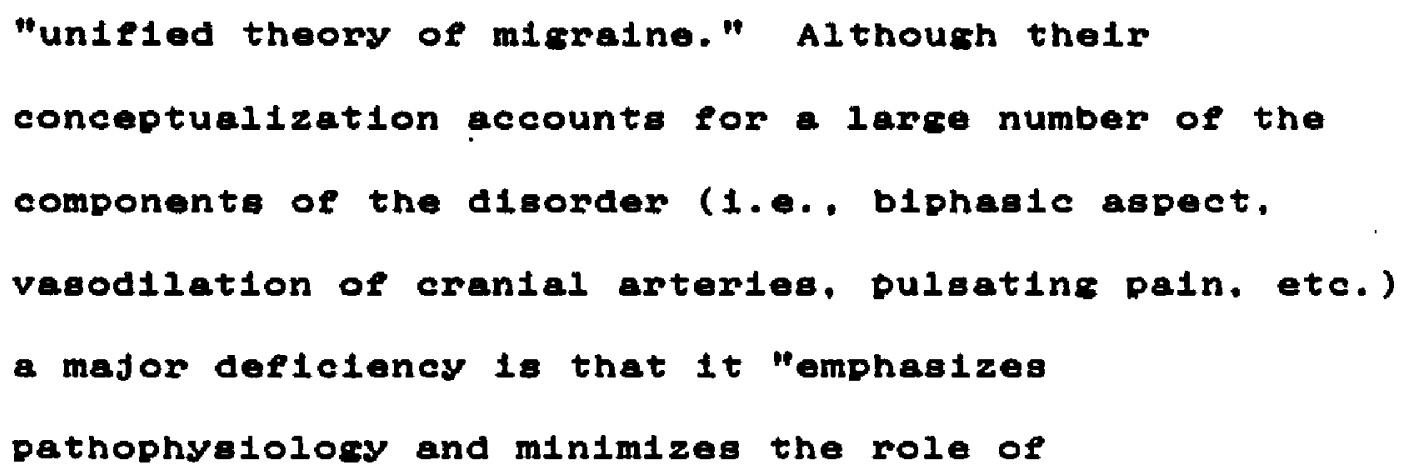




\section{Paycholorical Correlates. The traditional}

psychosomatic 11 terature 18 replete with

characterizationa of "the migraine personal1ty." The stereotype of the migralne oufferer 18 that of a "tenee, driving. obsessional perfectionist, with an Inflexible personality. who maintalns a store of bottled up resentments whlch neither can be expressed nor resolved" (Henryk-Gutt \& Rees. 1973, p. 142). Daless10 (1972) noted that $90 \%$ of the migralneurs he has treated were overly ambituous and preoccupled with echlevement and success. Almost all attempted to dominate or overcontrol their environments usualiy through acquisition of power. He added "many of these driving Individuals sald they had lost the ability to 'feel tired'. With few exceptions they were overtly perfectioniatic, persistent and exacting, attempting always to arrange or bring order wherever posalble" (Daless10, 1972, P. 369).

Although the notion of the "migraine personality" has been "the clinical lore" for many years. empirical Investigations attempting to acientifically confirm the exfatence of this "personality profile" have usually falled. Equivocal reaults have been the general rule (Cuspers, Altenkirch, \& Bunge, 1981; Henryk-Gutt \& Rees, 1973: Kudrow \& Sutkug, 1979: Rogado, Harrison, \& Graham, 1974; Waterg \& O'Connor, 1971), with most 


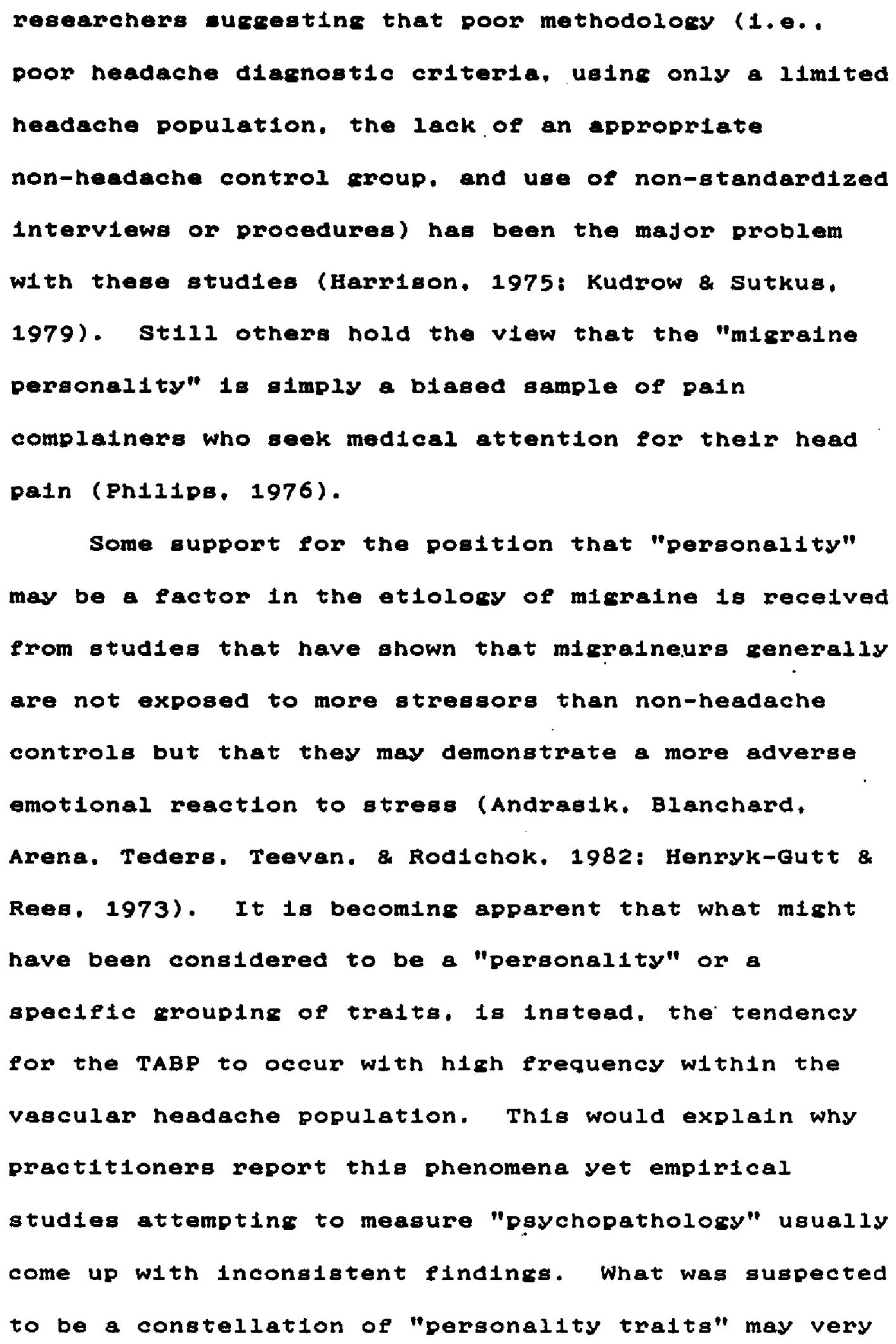


woll be Instead, the "tightly woven tapeatry" (Sparacino, 1979) that Rogenman and Friedman have written about prolifically.

\section{Muscle Contraction Headache}

Symptometolory. Muscle contraction or tension headache was described by the Ad Hoc Committee (1962) as "an ache or sensation of tightness, pressure or constriction; widely varied In Intensity. frequency and duration: sometimes lons lasting: commonis occipltal; and associated with muscle contraction in the absence of permanent structural change: usually as part of the Individual's reaction to Iffe stress." More recently. Olton and Noonbers $(1980)$, In a review of the adjectives used to describe muscle contraction headaches. found that such gtatements as "tightness." "pressure," "goreness," and "tIght band" were most commonly reported. It has further been suggested that the pain in this type of headache 18 dull. occastonally changing to a throbbling ache, and 18 usually bllateral (Appenzeller. Feldman, \& Frledman, 1979). The location of the pain varies greatly, and, though generally occlpital. It may radiate to the temporal, parietal, or Prontal reglons (Frledman, 1979).

$$
\text { studies of headache sufferers' diaries have }
$$

provided information relative to the characteristics of muscle contraction headache (Cohen \& McArthur, 1981; 
Friedman, 1979: Raskin \& Appenzeller, 1980).

Speciflcally, 1t has been found that the duration of

these headaches may range from a few hours to weeks or months of congtant pain, with the time of onset most often between the hours of four and elght A.M. and P.M. (Dlamond \& Dalessio. 1978). A glentelcant proportion of muscle contraction headache auferers report that thelr headaches increase in severity as the day procresses (Appenzeller et al. 1979). Pathophysiolory. Various theories have been offered to explain the origin of the pain in tension headache (Daless10, 1978; Dlamond a Dalessio, 1978: Kudrow, 1978; Wolff, 1963). All of these vlews share one thing in common: the importance of abnormal contractions of head muscles. Wolff and hla co-workers (Wolfe, 1963: Tunis \& Wolff, 1954) f1rst advanced the notion that the sustalned contraction of head muscles was responsible for the pain in tension headache. Subsequently, most of the research and conceptualization of muscle contraction headache has been based on their model. This is true even though much of their orlglnal work was based on small non-clinical samples in which extreme physical or pharmacological interventions were used to induce the onset of head pain. 
Although revlews of peychophyslological

Investigations of tension headache reveal a great deal of Inconsistencles in reaults obtalned by various researchers, findings concerning the relation between EMG and paln are suggestive that muscle contraction is still the basis for the experience of alscomeort. Current research in this area 1s attempting to determine if homogeneous subgroups of tension headache patients (1.e.. those with abnormal EMG during headache phase va. those patients who do not have elevated muscle activity) need to be evaluated separately. It 18 hoped that when theae two groups are examined ag discrete entities, clearer and more conclusive results should be forthcoming.

\section{The Present Study}

Recently, two Investigations of possible links between the TABP and headache heve been publighed in the sclentific literature. Although both produced encouraging results, both had weak methodologles which makes Interpretation and generalization difficult. Although both exploratory studies had their Individual faults. they provide an impetus to the present proposel.

H1cks and Campbell (1983) publighed the results of a survey they administered to 177 undergraduate students. Each participant responded to the student 
version of the JAS and estimeted the frequency with which they experienced teneion or mieraine headaches on a three-polnt scale with the following anchors: often. sometimes, never. Ualng a chl-square analys18, they found a relation between Type A/B and the "frequency of headache, $\mathrm{E}<.01, \mathrm{C2}=.05 . "$ Resulta revealed that the frequency of self-reported headache symptomatology was significantly greater In the Type A Individuals than in the Bs. Although the problems with this study's methodology are blatant (1.e.. both measures possess questionable rellabllty and validity), the results sugaest the feasibility of a more comprehensive Btudy.

The next atudy in this area appeared in the 11terature the next year. Woods, Morgan, Day, Jefferson, and Harris (1984) provided additional results with a better design. The data provided by these researchers came from two sources: (a) another aurvey of female undereraduates (replicated across two large Independent sroups) and (b) the sentor author's private practice patients, most of whom were diagnosed chronic headache sufferers. The survess from the undergraduate samples $(\underline{n}=237$ and 206$)$ revealed Identical results; Increasing frequencles of headache complaints (both vascular and tension symptoms) were significantly associated with higher scores on the Type 
A scale of the JAS and eta squared approximated .03. The data from the client population demonetrated a similar trend. Nearly $75 \%$ of the headeche patients were classifled as Type A (that 1s, they scored above the 50th percentile on the JAS Type A scale). Woods et al. (1984) concluded that the reaults of their Inveatigation atroncly suggested that the results be replicated on headache populations and extended to other non-CHD, vascular-related populations as well (e.s.. Raynaud's d1serse).

These results clearly revealed, albelt on a very small scale (clinical sample. $n=16)$. that a behavior pattern which has been only aggociated with coronary artery disease now can be considered to have Implications for other cardiovascular problems as well. The Implications are that the TABP, originaliy postulated to be a "centrally-10cated" construct can also affect the periphery of the human vascular gystem. It 18 Interesting to note that what was originaliy termed the "coronary-prone" behavior pattern. that 18 Type A, may very soon be considered the "vascular-prone" behavior pattern. In fact. Adler, et al. (1971) reported a "pressured behavioral pattern" very much like what is now termed Type A, contributing to cerebrovescular disease. 
Therefore 1 t 1 s the main purpoge of the present study to explore the relations between the TABP and other Important psychometric measures of chronic headache gufferers. The Investigation w111 firgt focus primerily on the incidence of the pattern in the entire sample of chrontc headache Individuala as well as within each diagnostic caterory. Secondly, the Invertigation w111 attempt to describe the association between traditional headache paln parameterg (ea.. Intensity. Frequency) and JAS groups.

The proposed etudy will also Investigate the peycholorical correlates of the TABP within this population. This comprehensive description of the pattern will sample correlates from three separate doma1na: paychopatholosy, social functionins, and health beliefs and behaviors. The need to pigorously Investisate peychopathological aspects of the TABP has been previously addreseed. As well, the probeble differences between Type $A$ and $B$ individuals related to Interpretations of atress levels and health behaviors has been documented. The most active area of emplrical research within the Type A realm currently involves the aseesement of social akill development of Type $A$ and $B$ 1ndividual. Therefore, measures of assertion and social functioning have been included. 


\section{Experimental Hypotheses}

Based on the research 11 terature summerized in

this proposal, the followlns primary hypotheses are presented:

(a) A signiflcantly larger proportion of Type As will be found within the migraine (vascular headache) sample compared to the muscle contraction headache sufferers; this 1s primarliy based on the view that the coronary-prone behavior pattern needs to be expanded to encompass other vascular disorders, most particularly migralne headaches. Previously, retrospective studies documented earlier sugrest this notion.

(b) Headache frequency In Ind1viduals will be positively correlated with JAS measures; retrospective studies noted earlier have sugrested this relation. (c) Headache Intensity ratings will be related to JAS scores: Type A Individuals will report less intense headeches than Type Bg: this prediction 1 s based on the gtudies that demongtrate that Type A Individuals tend to underestimate and under-report physical symptoms in the laboratory and more naturalistle settings. The following gecondary hypotheses are also Buggested:

(d) The TABP will be relatively unrelated to valid measures of paychopathology in a headache population: superior gtudies in the eleld document that the 
relations between meesures of the TABP and paychopathology are weak. Th1s will be the e1rst study to examine this relationship within a clinical population.

(e) The TABP w11l be related to valld measures of social functioning in a headache population; research Implies that level of social akill and Interpersonal functioning may be important components in the development and malntalnance of Type A behavior. (f) The TABP will be related to instruments that measure health bellefs and behaviors in a headache population; relevant research literature lmplies that 11Iness behaviors and health bellef differences exist. between $A s$ and $B B$, however no investigation has directly investisated this relation. (a) Type As in a headache population will report simfificantly less stress than Bs on the dally measures of otrese while ldentifying equivalent numbers of dally encountered stressful events. 
TABP and Headeche

Method

\section{Subjects}

Reseerch subjects were recrulted through newspaper advertigements and referrals from the medical

community. A sample of 30 tension headache sufferers and 30 migralneure comprised the headache population for the study.

Analyser of participants' demographic information revealed two Blsnificant differences between migraine and muscle contraction volunteers. There was a olentelcantly larser number of men than women in the muscle contraction group, $\mathrm{X} 2(1)=5.96 . \mathrm{p}<.02$. As well. there were elentificantly more blacks in the migralne aample, $\times 2(1)=5.19, p<.02$. Table 1 describes race and sex distributions for the sroups. There were no sienfelcant differences between the groups on any other demographic variable. See Table 2 for age digtribution by group and Table 3 for other demographic information. Characterlatics of the sample in this invegtigation was representative of typical headache amples used in past research efforts. The following criteris were used in reaching headache diagnostlc decisions (Ad Hoc, 1962): tension neadache gufferers were charactertzed by the presence of typical muscle contraction pain complaints such as aching, dull pain, tightness, tension and band-like or 
TABP and Headache 42

Table 1

Distribution of race and sex among JAS and HA groups $(n=60)$.

\begin{tabular}{lcccc}
\hline Group $^{\star}$ & \multicolumn{2}{c}{ Race } & \multicolumn{3}{c}{ Sex } \\
\hline & White & Black & Male & Female \\
MG-Type A & 13 & 3 & 1 & 15 \\
MG-Type X & 6 & 3 & 1 & 8 \\
MG-Type B & 4 & 1 & 1 & 4 \\
MC-Type A & 7 & 0 & 3 & 4 \\
MC-Type X & 13 & 0 & 2 & 11 \\
MC-Type B & 9 & 1 & 6 & 4 \\
\end{tabular}

${ }^{*} M G=$ migraine, $M C=$ muscle contraction 
TABP and Headache 43

Table 2

Mean and standard deviation for age by group.

\begin{tabular}{lcl}
\hline Group $^{*}$ & $\underline{n}$ & $\underline{M}(\underline{S D})$ \\
\hline MG-Type A & 16 & $36.18(9.3)$ \\
MG-Type X & 9 & $35.44(6.1)$ \\
MG-Type B & 5 & $41.40(4.0)$ \\
MC-Type A & 7 & $43.71(10.7)$ \\
MC-Type X & 13 & $39.46(5.5)$ \\
MC-Type B & 10 & $40.09(14.0)$ \\
\hline *. & &
\end{tabular}


TABP and Headache 44

\section{Table 3}

Additional demographic information $(n=60)$.

Marital Status

Single

Married

$18 \%$

Divorced

$61 \%$

$20 \%$

- Educational Background *

No High School Diploma

High School Graduate

Some College

$25 \%$

College Graduate

$29 \%$

$41 \%$

Annual Income

Less than $\$ 10,000$

$\$ 10,000-29,000$

$\$ 30,000-49,000$

Over $\$ 50,000$

$2 \%$

$32 \%$

$47 \%$

$19 \%$

Employment Status

Part-time

$16 \%$

Full-time

$63 \%$

Homemaker

Unemployed/Retired

$14 \%$

$7 \%$ 
cap-11ke preasure. Further, the presence of no more than one of the followlng vascular headache aymptoms were reported: neusea and/or vomiting, unilaterel pain. throbbins pain. viaual prodromes and relief of pain from vasoconstrictive druss. In addition. aubjects Included In this Investigation all reported experiencine at least two headechea per week for at least one year.

Headache auffererg meetino three of the following diagnostic eriteria will be Included within the migralne category: unilateral pain described as throbbing or pulatins. vomiting and nausea, relief from vasoconstrictive medication, and history of diagnosed mieratne headache in a first-order family member. Individuels meeting the above criteria and reported aufferine at least two headaches per month for at least one year participated in the study. Those Individuala who met the criterla for both groups (combination or mixed headache aufferens). that 18. guffer from two diatinct types of neadaches. were not Included in this preliminary invegtigation. In addition to the inclusion criteria described above, a number of conditions excluded individuals from participation. These Included: sinus headaches (with a confirmed diagnosis) Indigtingulghable from other headaches. temporomandibular jolnt gyndrome (based on a 
confirmed dentigt" diagnosis), otruetural damege or phyalcal trauma (such as concusatons or pinched nerves) and past or present major peychiatrie 111nese (es.. paychosis). Additional1y, Bubjects who did not have a neurological cereening lncluding at least a CT acan. GkU11 X-Ray. Or electroencephalogram (EEG) were excluded from the present etudy.

Assignment to headsche category was beged on two 1ndependent diagnoger. A boerd-certified neuroloelst dianosed all subjecta based on en interview and neurolosical examination. Also, a doctoral student in medical/clinical psychology diagnosed the subjecta using the exiteria described above. Discrepancies between the deciaions of the two Individuals were discussed and resolved before lncluding a person in the study. If an egreement could not be reached regarding a subject's diagnosis, that Individual was excluded from the study.

Each Individuals essianment to JAS group memberghtp was baged on the participanta JAS acore (acale A). Those participants scoring at the 25 th percentile or lower according to national group norms were considered Bs. Individuals Bcoring at the 75 th Xile or higher were considered AB. Thoge Individuals Bcoring between these two cutoffs were congldered Xs. 


\section{Materiale}

One time meagures. Subjects will be given the following paychometic Instruments during their first geseion:

Jenking Activity Survey. The Jenkins Activity SurveyForm C (Jenk1ns, Zyzansk1, \& Rosenman, 1979) w111 be used to catesorize the participants on the Type $A / B$ parameter. As noted in an earlier part of the proposel. the JAS 18 the most popular and widely accepted paper and pencli measure of the TABP. Further, it has been argued that the JAS may be the only Inetrument which approaches the SI'B ab1l1ty to correlate alenificantly with CHD. Finally, another major advantage of the JAS 18 that 1 t provides not only a slobal Type A measure but three factor analyticaliy-derlved subscales: hard-delving \& competitive, Job-involvement, and apeed \& Impatience. The Speed and Impatience Factor (Factor $S$ ) deals with the time urgency revealed in the etyle of behavior of the Type A Individual. Those gcosing high on this factor eat very rapidly. become impatient with the converation of others, hurry alons other people, have strons tempers, and become 1rritated easily. The Job Involvement Factor (Factor J) expresses the derree of dedication to occupational activity. Typtcally. persons sconing high on this factor report having a 
challenglns, hish-pressure job. They work overtime and confront Important deadlines. They prefer promotion to a pay ralse. but usually received both in the last fow years. The Hard Drivins and Competitive Scale (Factor H) Involves perceptiong of oneself as belng hard-driving. consclentions, responsible, serlous, competitive, and putting forth more effort than other people. A description of all JAs 1tems and their factor loadings, alons with the procedures used to construct factor scores, 1s given by zyzanski and Jenkine (1970).

IBI. The Illness Behavior Inventory (Turkat \& Pettegrew, 1985) was developed and valldated as a 20-1tem self-report measure of illness behavior. Published results Indicated that the IBI posiesses acceptable levels of Internal consigtency (Cronbach's alpha $=.89)$, test-retest rellability $(\underline{\underline{r}}=.90)$, as well as discriminent, concurrent and predictive validity. The instrument was developed as a dependent measure with yarlous medical patients who exhibit excessive or Inappropriate 111ness behavior. Each Item on the scale 18 answered on a 6-polnt likert-type scale from "vers descriptive of me" to "not at all descriptive of me." This particular scale adopts the definftion that iliness behavior 1s "an overt behavior 
performed by an Individual which Indicetes that he or she 1s physically 111 or In physical discomfort." IBQ. The Ilinese Behavior Questionnalre (2nd Edition) was developed by Pllowgky and spence (1983) as a belf-report measure to record aspects of 111ness behavior. "particulary those attitudes that ouggest Inappropriate or maledaptive modes of responding to one's state of health" (p. 1). The 62-1tem questionnalre ylelded four factor analytically derived measures: hypochondriasis, disease conviction, peychological ve. somatic concern, and 1rritability. Empirical studies demonstrate this instrument contains adequate rellabilty; test-retest reliabilities are .76 . .76 . .84 , and .85 for the aforementioned scales. respectively. Additional peychometric information and normative data for various medical and control sroups are avaliable from in the manual (Pllowgky \& Spence. 1983).

HLC. Wallston, Wallston. Kaplan, and Maldeg (1976) reported on the development and validation of the Health Locus of Control scale. The HLC 1s a specific meacure of expectancies regarding locus of control developed for prediction of health-related behaviors. H1gher scores are Indicative of Individuals who percelve themselves as an active and Involved determinant of their own health. This 11-1tem 
Ingtrument 1e acored in a 6-point, Likert-type format from "Btrongly agree" to "gtpongly disemree." Reported test-petent reliability 18.72.

MMPI. The Minnesota Multiphasic Pepsonelity Inventory (Hathaway a McKinley, 1943) Ia the most extengively used. researched, and accepted measure of peychopathology (Butcher \& Tellesen, 1978). Aa a self-report inventory that includes several measures of peychopetholory. the MMPI has become the most widely used descriptive instrument and criterion measure in clinical paycholocy. The 544 true-felee 1teme yiela several Interreleted scale scorea. Dahlstrom, Welsh. and Dahlstrom ( 1975 ) present a compreheng1ve review of the paychometric properties of this instrument. STAI. The State Trait Anxiety Inventory-Trait (Splelberser. Gorsuch, a Lushene, 1970) was destaned to be a self-administered meabure of tratt anxiety. The scale 1 one of the most widely used mearures of the paychologlcal congtruct, anxiety. Valialty and reliability atudies as well as normative data for many varied populations are avaliable in the manual (spe11berser. Gorsuch, \& Lushene, 1970). The 1nventory consigta of 20 iteme rated on a four-point acale ranging erom "not at a11" to "very much so." Zun*. The Zung Self-Ratino Depresaton scale was developed to be a short, comprehensive, and reliable 
Instrument that measures the beverity of depresion (zuns, 1965). It conta1ns 20 1teme that were senerated to tap features of depreasion that had been 1dentifled in previous factor analytic studies of depreasion (Friedmen, Cowltz, Cohen, \& Granick, 1963). Each 1tem 1a rated on a four-point acale with anchors rancing from "a I1ttie of the time" to "most of the time;" a depressive index 18 generated by summing the 1 tem scores. Reliablitty and validity etudies reveal this instrument to be a falriy ugeful meagure of depresilon that taps cornitive, behavioral, and emotional spherea of the syndrome.

SAD/FNE. The Social Avoldance and Distresa acale and the Fear of Neretive Evaluation scale were developed by Wetson and Friend (1969). Both scaleg were developed to mearupe alfferent abpecte of boclal anxiety. The SAD was developed to measure the experience of distreas. discomfort. fear. and anxiety in social a1tuations. The FNE measures a congtruct defined as fear of recelving negative evaluations from others; The Instruments consist of 28 and 30 descriptive statementa, respectively, and aubjecta are asked to decide if each 1 tem describes themselves. The scales have very high indexes of homogenelty (KR-20=.94 for both scales) and posgess sufficient reliabilitieg: 
test-retert rellability was .94 and .79 for the FNE and SAD, respectively.

Aseertion Inventory. Gambrill and Richey (1975) developed this 40-1tem self-report instrument to measure the construct of assertiveness. Two relatively Independent ecores are derived: a probability measure rating how $11 k e l y$ the aubject 1 s to encrege In the behavior (test-retest rel1abil1ty $=.81$ ), and a d1scomfort meature, Indlcatine the amount of discomfort he/ahe would experience if behaving in that way (test-retest rellab1l1ty $=.87$ ). Each 1tem 1s rated on a P1ve-point scale from "none" to "very much." In a recent critical I1terature review of "essertion Inventorles," Furnham and Henderson (1984) concluded that the uniqueness of this instrument, that 18 , it does not yleld one slobal assertion index. In confunction with 1t'B psychometrically-sound characterlstics, It produces a supertor assertion measure.

Da11y measureg. Subjects were required to f1ll out a dally headache record which monltored headache frequecy, Inteng1ty, as well as degree of Incapacitation and medication 1ntake. In addition. particlpants completed the following two measures on a dally basis throughout the study: 
DSI. The Dally Stress Inventory (Brantley, Wacsoner, Jones. \& Rappaport, in press) 1s a 58-1tem self-report measure for the datly aseesement of sources and Individualized Impact of relatively minor stressful' events. It was designed to aseses sources of stress not typically assessed by major life event scales. Studies demonetrate that the acale poseeses adequate rellability and valldity coefflclents (Brantley et al.. In preas). Adminatration of the scale produces three scores: the number of daliy atress events (FREQ), the percelved total masnitude of the stressors (SUM), and the average streas index (AIR).

\section{Procedure}

The present study Involved elght weeks of self-monltorlng by all subjects. During this perlod of time, subjects met In small sroups bi-weekly with the Investigator.

First gesion. During the first visit, subjects completed an informed consent form. subjects were also administered all of the instruments listed under "one time measures." They were then supplied with the necessary forms for and instructed in the use of the daliy monitorine procedures.

Second session. During the second visit, research participants returned with their home records for the flrst two weeks. Any errors or misunderstandings in 
the self-monitorine procedure were clarifled and/or corrected. Home records were collected from subjects and new headeche records and daily aele-monitorins materials (1.e.. DSI) were distributed for the Pollowlng per1od.

Th1rd. Fourth, and Fifth sessions. These meetinas were similar in neture to the eecond geseion in that self-monitoring date were collected, questions and probleme were addressed, and new forms were distributed. During the last segsion. at the end of the eighth week of monitoring, arrangements were made for participants to recelve Individual headeche treatment. 
TABP and Headache

\section{Results}

\section{Independent Verlable}

The Jankine Aotivity Survey (JAS) Type A Scale was ues to divide the semple Into Types $A, x$, and $B$ clasalfications. As noted earlier, thoge Individuals Bcoring at the 25 th percentile laccording to national norms) or lower were considered Type B. Participanta whose JAS-A Bcale score was at the 75 th percentile or higher was considered Type A. Those Individuala whose score l1es between the 25 th and 75 th percent1les were claselfled as Type X (1.0. Individuala who have gome Type A. and Type B charecteristica).

Incldence of TABP in Headache Population The main purpose of this study was to investisate the Incidence of the TABP in a chronic headache population. It was hypothesizad that a alenificantiy lares proportion of mieraineurs would be cleselfied as Type A a compared to muscle contraction headache eufferers. A $2 \times 3$ (Headache diagnostic rroup by JAS group) cht-square analysib revealed a sianificant difference in the distributions, $\times 2(2)=5.92, p<$ $.05:$ see Table 4). S1eniflcantly more Type A Individuala were found in the migralne diagnostic group as compared with the muscle contraction headache group. Three $2 \times 2$ follow-up chl gquare analyses were performed to agcertain where the gigniftcant 
TABP and Headache 56

Table 4

Frequency of sample by JAS X HA.

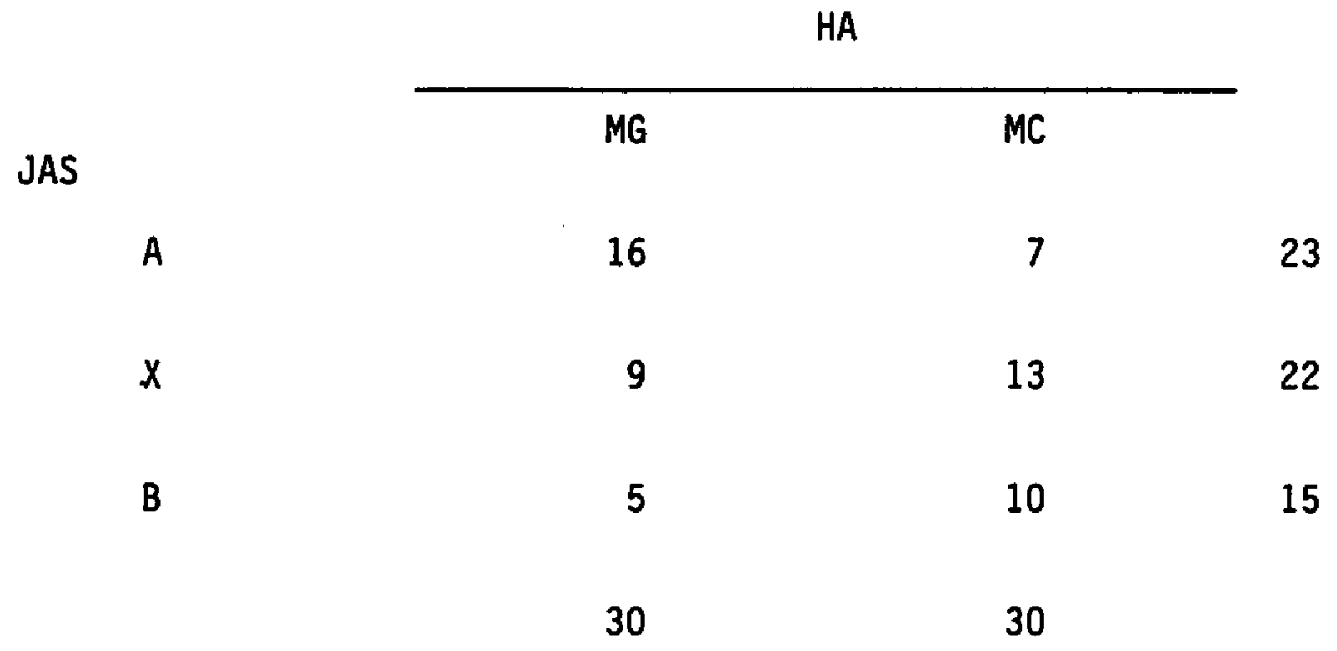


differences were within the signifleant $2 \times 3$ analysis. See Tables 5, 6, and 7 for theee enalyges. Sisnificant differences were found between $A B$ and Bs es well as Ag and $\mathrm{Xa}$. Non-signficant resulta were obtalned for the ch1 gquere analyals between $B s$ and $X s$.

\section{Headache Deta}

\section{Data Reduction}

Mean measures of headache Intensity (HAI; 1-10 ratine ecelet see appendix for reting form) were computed for each eubject. These data were obtalned from dally headache self-monttoring forms. Mean measurea were obtained by averaging each headache Intensity rating for the entire two month monitoring perlod. The average number of headache days per month for the elght week perlod (HAF) was also be recorded for each subject $(0-28)$.

\section{Data Analyseg}

The two head pain parameters (HAI \& HAF) were analyzed by 2 X 3 (Type of Headache by JAS Group) completely randomized MANOVA. Results indlcated eloniflcant differences for JAS group, multiveriate F (4. 108) $=2.76 . \mathrm{p}<.03$ and headache diagnosis. multivarlate $E(2,53)=7.03 . \mathrm{P}<.002$. The Interaction of these main effect was not significant. multivariate $F(4,108)=.62$, $p<.66$. A follow-up two-way ANOVA for HAI revealed gignificant differences 
TABP and Headache 58

Table 5

Frequency of gample by JAS/HA degirnetion

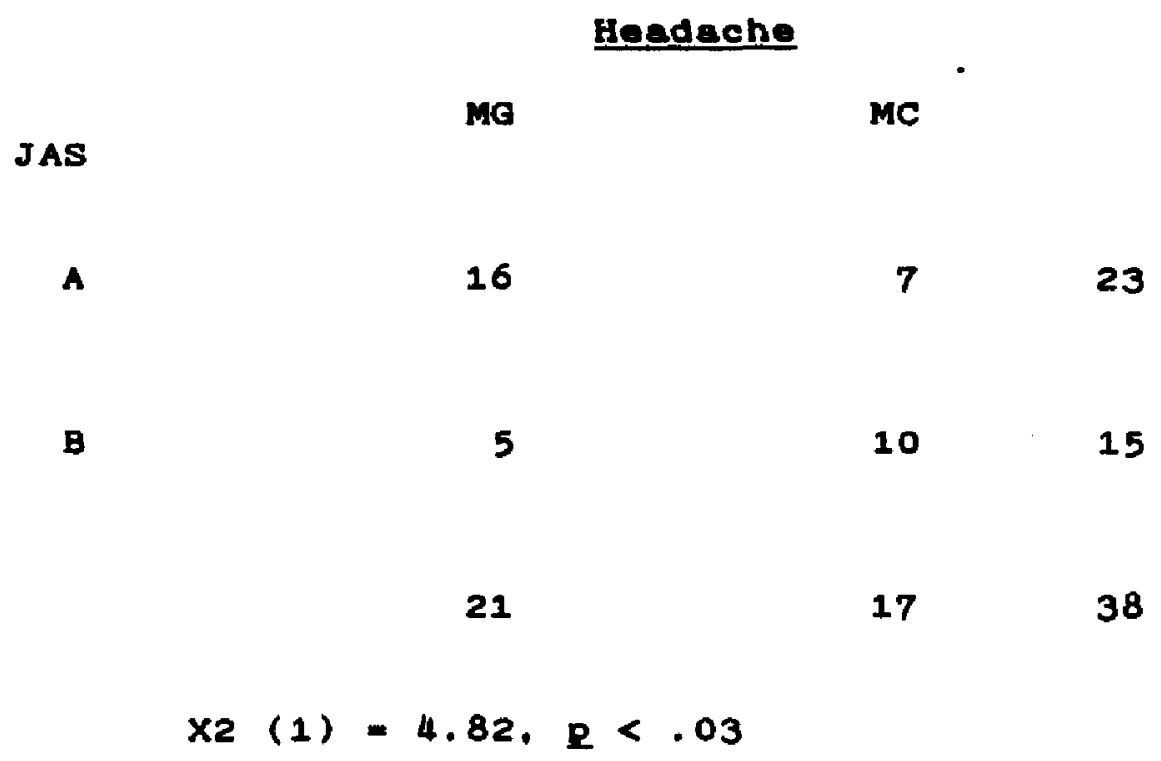


Table 6

Frequency of sample by JAS/HA desirnation.

Headeche

MG MC

J AS

$\mathbf{A}$

16

7

23

$x$

9

13

22

25

20

45

$\times 2(1)=3.74, p=.05$ 


\section{Table 7}

\section{Frequency of sample by JAS/HA deglenation.}

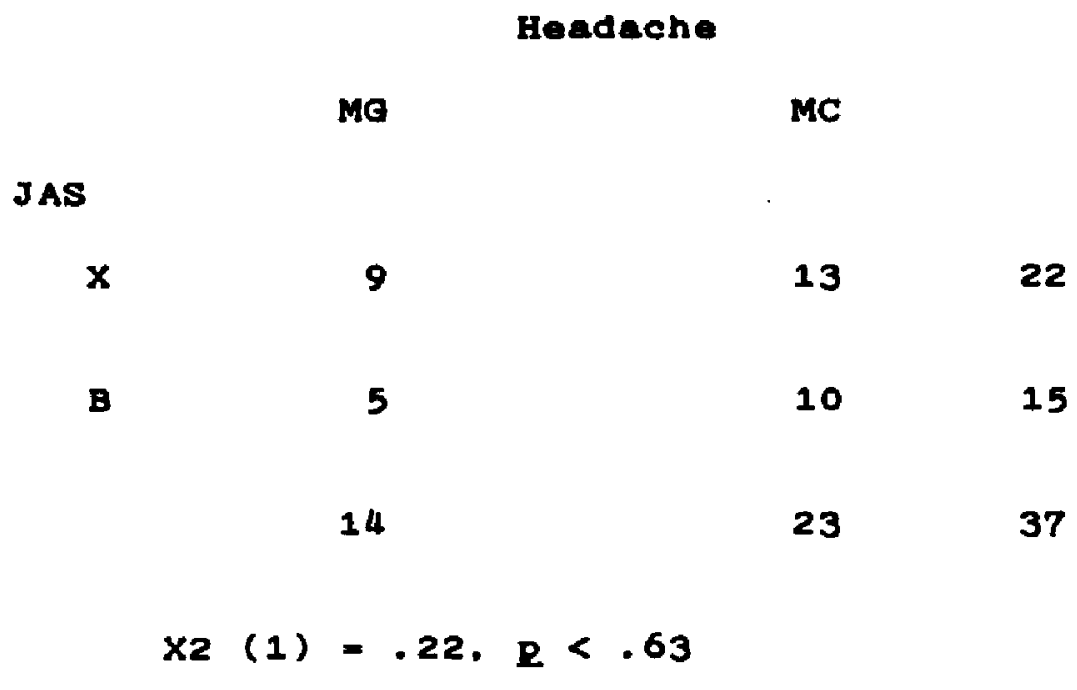


TABP and Headache 61

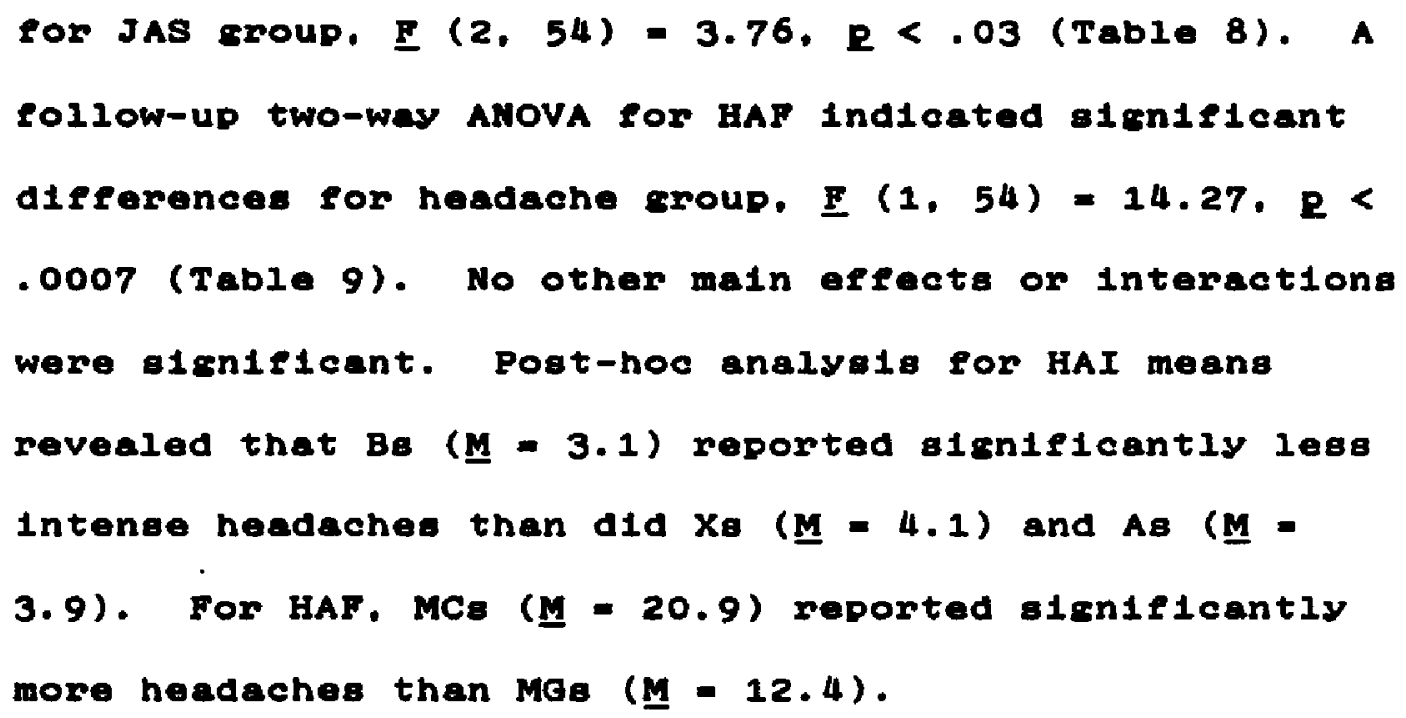

\section{Peycholoric Data}

One-t1me mearures

Subjects data for all one-time dependent measures (1.0., IBI, SAD, MMPI, IBQ, FNE, HLC, STAI, zung, Ageertion Inventory) were analyzed in $2 \times 3$ (Type of Headache by JAS Group) completely randomized MANOVAa within domeins (1.0.. social functioning. peychopatholory, health bellefa and behavione) when posa1bie.

Paychopetholory. A 2 X 3 MANOVA for the gtandard MMPI validity (1.e., L, F, \& K) and clinical (1.2, 3. 4. 6. 7. 8. 9. \& 0) scales revealed no gientelcant main effecta or Interaction (Table 10). A 2 X 3 MANOVA using the zuns and STAI scores as dependent measures alao ahowed no bianificant effecta (Table 11). Social functioning. The instruments within this domaln were the Social Avoldance and Digtreag Scale 
TABP and Headache 62

Table 8

Anova summary table for headache intensity rating $(n=60)$.

\begin{tabular}{lrrrrrr}
\hline Source & SS & df & MS & F & $\mathrm{p}$ & $\mathbf{Z}^{2}$ \\
\hline JAS & 835.44 & 2 & 417.72 & 3.76 & .03 & .12 \\
HA & 74.91 & 1 & 74.91 & .68 & .42 & \\
JAS X HA & 195.21 & 2 & 97.61 & .88 & .42 & \\
Error & 5992.27 & 54 & 110.99 & & & \\
\hline
\end{tabular}


TABP and Headache 63

Table 9

Anova summary table for headache frequency $(n=60)$.

\begin{tabular}{lrrrrrr}
\hline Source & SS & df & MS & F & p & $x^{2}$ \\
\hline JAS & 295.05 & 2 & 129.52 & 1.97 & .14 & \\
HA & 936.75 & 1 & 936.75 & 14.27 & .0007 & .18 \\
JAS X HA & 72.72 & 2 & 36.36 & .55 & .58 & \\
Error & 3544.98 & 54 & 65.65 & & & \\
\end{tabular}




\section{TABP and Headache 64}

Table 10

Manova results for MMPI scales $(n=54)$.

\begin{tabular}{crcc}
\hline Source of Variance & $F$ & df & p \\
\hline JAS & 1.22 & 26,74 & .25 \\
HA & .92 & 13,36 & .55 \\
JAS $X$ HA & .55 & 26,72 & .92 \\
\hline
\end{tabular}




\section{TABP and Headache 65}

\section{Table 11}

Manova results from STAI and Zung scales $(n=60)$.

\begin{tabular}{ccccc}
\hline Source of Variance & F & df & $\underline{p}$ \\
\hline JAS & .73 & 4,108 & .57 \\
HA & .73 & 2,53 & .49 \\
JAS $X$ HA & .87 & 4,108 & .48 \\
\hline
\end{tabular}


TABP and Headache 66

(SAD) and the Fear of Negative Evaluation Scale FNE). A 2 X 3 MANOVA uajng aubjectB' SAD and FNE scores as dependent measures ylelded a sinfficant JAS by HA d1acnosis Interaction, multivariate $F(4,101)=3.41$. $p<.01$ (Table 12), A $2 \times 3$ ANOVA for the FNE revealed no significant interection effects (Table 13). However, $2 \times 3$ ANOVA for the SAD revealed a alenificant interaction, $F(2,51)=4.84, \mathrm{R}<.01$. (See Table 14). Figure 1 contains group means for SAD data. A post-hoc olmple effects test revealed that the mean for the MC-Bs was gionificantly higher than the MG-B mean, $\mathrm{P}<.05$. No other group means were sionflcantiy different from each other.

A $2 \times 3$ MANOVA for the two subscores of the Assertion Inventory (1.e., Degree of D1scomfort \& Response Probability) revealed no significant differences. (See Table 15).

Health Beliefs and Behaviore. A $2 \times 3$ MaNova for four scales of the Illnese Behavior Questionnatre (Scales 2, 3, 7, \& Whiteley Hypochondriagis) revealed a elenifleant effect for JAS eroup. multivariete F ( 8 , $92)=2.08 . \mathrm{p}<.05$ (Table 16). There were no other elgnificant effects. Tables 17, 18, 19, and 20 present ANOVA summary tables for IBQ Scales 2, 3, 7, \& Whiteley Hypochondriasis, respectively. These anslyses revealed only two significant differences, both main effects for 


\section{TABP and Headache 67}

Table 12

Manova results for SAD/FNE scales $(n=57)$.

\begin{tabular}{|c|c|c|c|}
\hline Source of Variance & $\mathbf{F}$ & $d f$ & $\mathrm{p}$ \\
\hline JAS & .17 & 4,101 & .95 \\
\hline HA & .37 & 2,50 & .70 \\
\hline JAS $X$ HA & 3.41 & 4,101 & .01 \\
\hline
\end{tabular}




\section{TABP and Headache 68}

Table 13 .

Anova summary table for FNE scale $(n=57)$.

\begin{tabular}{lrrrrrr}
\hline Source & SS & df & MS & F & p & $\eta^{2}$ \\
\hline JAS & 34.17 & 2 & 17.09 & .27 & .77 & \\
HA & 33.50 & 1 & 33.50 & .53 & .48 & \\
JAS X HA & 321.23 & 2 & 160.62 & 2.51 & .09 & \\
Error & 3201.20 & 51 & 64.02 & & & \\
& & & & & \\
\hline
\end{tabular}


TABP and Headache 69

Table 14

Anova summary table for SAD scale $(n=57)$.

\begin{tabular}{lrrrrrr}
\hline Source & \multicolumn{1}{c}{ SS } & df & MS & F & p & $\eta^{2}$ \\
\hline JAS & 18.55 & 2 & 9.27 & .18 & .83 & \\
HA & 3.15 & 1 & 3.15 & .06 & .79 & \\
JAS X HA & 419.53 & 2 & 245.76 & 4.84 & .01 & .16 \\
Error & 2540.66 & 51 & 50.81 & & & \\
& & & & & & \\
\hline
\end{tabular}


TABP and Headache 70

Figure 1.

RESULTS: Social

Functioning

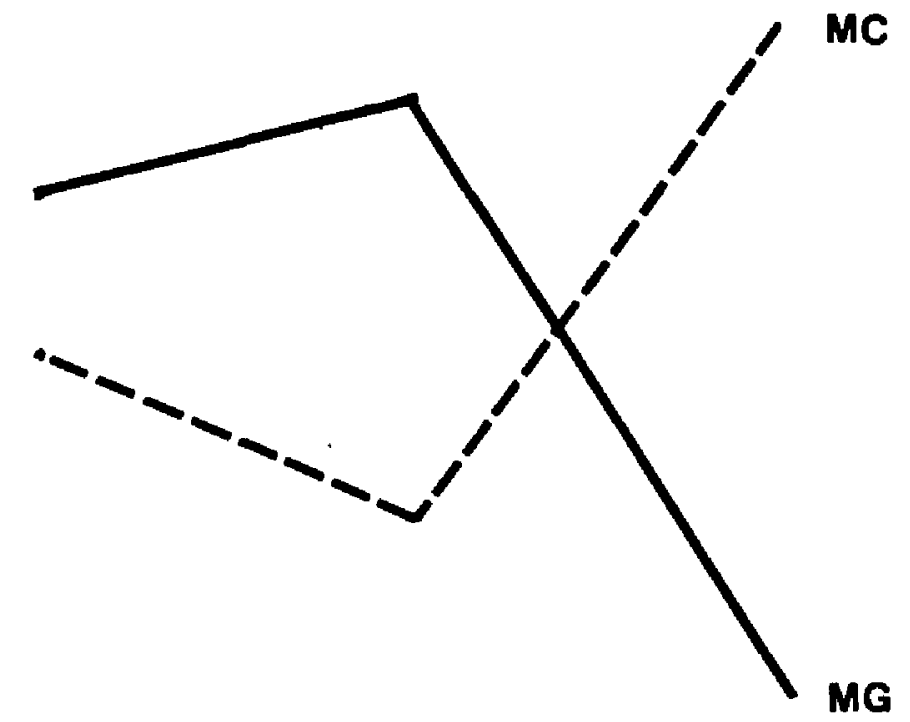

A

$x$

B

JAS

GROUP 
TABP and Headache 71

Table 15

Manova results for Assertion Inventory scales $(n=46)$.

\begin{tabular}{ccccc}
\hline Source of Variance & F & df & \multicolumn{1}{l}{$\mathbf{p}$} \\
\hline JAS & .74 & 4,80 & .57 \\
HA & .51 & 2,39 & .61 \\
JAS X HA & 1.54 & 4,80 & .19 \\
\hline
\end{tabular}




\section{TABP and Headache 7\%:}

Table 16

Manova results for IBQ scales $(n=54)$.

\begin{tabular}{crrl}
\hline Source of Variance & $\mathrm{F}$ & $\mathrm{df}$ & $\mathrm{p}$ \\
\hline JAS & 2.08 & 8,92 & .05 \\
HA & .84 & 4,45 & .51 \\
JAS $X$ HA & 1.93 & 8,92 & .07 \\
\hline
\end{tabular}


TABP and Headache 73

Table 17

Anova summary table for IBQ scale 2 (Disease Conviction; $n=54$ ).

\begin{tabular}{lrrrrrr}
\hline Source & \multicolumn{1}{c}{ SS } & df & MS & F & P & $\eta^{2}$ \\
\hline JAS & 9.18 & 2 & 4.59 & 2.32 & .11 & \\
HA & 2.96 & 1 & 2.96 & 1.50 & .22 & \\
JAS X HA & .52 & 2 & .26 & .13 & .87 & \\
Error & 95.11 & 48 & 1.98 & & & \\
& & & & & & \\
\hline
\end{tabular}


TABP and Headache 74

Table 18

Anova summary table for IBQ scale 3 (Psycho vs Somatic; $n=54$ ).

\begin{tabular}{lrrrrrr}
\hline Source & SS & df & MS & F & p & $\eta^{2}$ \\
\hline JAS & 4.94 & 2 & 2.48 & 3.40 & .04 & .12 \\
HA & .01 & 1 & .01 & .01 & .87 & \\
JAS X HA & 2.17 & 2 & 1.09 & 1.50 & .23 & \\
Error & 34.86 & 48 & .73 & & & \\
\end{tabular}


TABP and Headache 75

Table 19

Anova summary table for IBQ scale 4 (Irritability; $n=54$ ).

\begin{tabular}{lrrrrrr}
\hline Source & SS & df & MS & F & p & $\eta^{2}$ \\
\hline JAS & 1.37 & 2 & .68 & .60 & .56 & \\
HA & 1.37 & 1 & 1.37 & 1.20 & .28 & \\
JAS X HA & .76 & 2 & .38 & .34 & .72 & \\
Error & 54.36 & 48 & 1.13 & & & \\
\hline
\end{tabular}




\section{TABP and Headache 76}

Table 20

Summary table for IBQ Whiteley Hypochondrias is Scale $(n=54)$.

\begin{tabular}{lrrrrrr}
\hline Source & \multicolumn{1}{c}{ SS } & df & MS & F & $\mathrm{Q}$ & $\eta^{2}$ \\
\hline JAS & 44.77 & 2 & 22.38 & 3.01 & .05 & .11 \\
HA & .65 & 1 & .65 & .09 &. .76 & \\
JAS X HA & 34.47 & 2 & 17.23 & 2.32 & .11 & \\
Error & 356.60 & 48 & 7.43 & & & \\
& & & & & & \\
\hline
\end{tabular}


JAS eroup. Sleniflcant reeulte were obtained for scale 3. $F(2,48)=3.40, E<.04$ and Wh1teley Hypochondriasis Scale, $\mathrm{E}(2,48)=3.01, \mathrm{P}<.05$. For Scale 3. sroup meane were $1.60,1.12$, and .75 for AB, XB, and BE, reapectively. A Tukey's tent revealed a signtficant difference between Type $A s$ and $B s$. No other group mean differences were obtalned. For the Whiteley Hypochondriasia Scale, exoup means were 2.58 , 4.73, and 4.13 for Type $A, X$, and B, respectively. A Tukey'g test revealed algniflcant difference between Type As and the other two spoups. No other sienfelcant differences were obtalned.

A $2 \times 3$ ANOVA for the Health Locus of Control revealed no significant differences. (See Table 21). A $2 \times 3$ ANOVA for the Iliness Behavior Inventory revealed a significant main effect for headache degnosis, $\mathrm{E}(1,53)=7.17, \mathrm{p}<.009$. Group meang were 70.14 and 58.44 for MGs and MCs, respectively. A glenificant effect was aleo obtalned for JAS group. F $(2.53)=4.41 . \mathrm{R}<.02$ (Table 22). Group means were 55.47. 66.14, and 72.50 for $A s$, Xs, and Bs, respectively. A Tukey's test for JAS means revealed a eleniflcant difference between $A B$ and $B g$ only. $P<.05$. Dally measures

Dete Reduction. Dally Stress Inventory scores (FREQ. SUM, \& AIR) were computed for each participant 
Table 21

Anova summary table for HLC $(n=56)$.

\begin{tabular}{lrrrrrr}
\hline Source & \multicolumn{1}{c}{ SS } & df & MS & $F$ & $\mathrm{p}$ & $\boldsymbol{\eta}^{2}$ \\
\hline JAS & 46.64 & 2 & 23.32 & .42 & .67 & \\
HA & 4.05 & 1 & 4.05 & .07 & .78 \\
JAS X HA & 228.15 & 2 & 114.08 & 2.05 & .14 \\
Error & 2780.92 & 50 & 55.62 & & & \\
\end{tabular}




\section{Table 22}

Anova summary table for IBI $(n=59)$.

\begin{tabular}{lrrrrrr}
\hline Source & SS & df & MS & F & $\mathbf{p}$ & $\boldsymbol{\eta}^{2}$ \\
\hline JAS & 2468.15 & 2 & 1234.07 & 4.41 & .02 & .13 \\
HA & 1996.18 & .1 & 1996.18 & 7.17 & .009 & .14 \\
JAS X HA & 312.85 & 2 & 156.42 & .56 & .58 & \\
Error & 14761.63 & 53 & 278.52 & & & \\
& & & & & & \\
\hline
\end{tabular}


for the flrat 28 days of the monitoring period. The frequency of 1 tem endorsement (FREQ). the total of these endoreemente (SUM) and the suM divided by the FREQ (average Intensity rating: AIR) were each averaged for all subjects, yleldins three dependent measures per subject.

Data Analya18. Obtalned DSI means were aubjected to a $2 \times 3$ ManOVA. Resulta revesied no significant differences (Table 23).

All group means for all dependent measures can be found in the appendices. 
TABP and Headache 81

Table 23

Anova results for DSI scales (FREQ, SUM, AIR; $n=49$ ).

\begin{tabular}{cccc}
\hline Source of Variance & $F$ & df & $\mathbf{p}$ \\
\hline JAS & 1.19 & 6,84 & .32 \\
HA & 2.56 & 3,41 & .07 \\
JAS X HA & 1.35 & 6,82 & .23 \\
\hline
\end{tabular}


TABP and Headache

\section{Discuesion}

The primary purpose of this investigation was to examine the distribution of Type $A$ and $B$ Individuals within a chronic headache population. Specifically, It was hypothesized that there would be a signiflcantly larser proportion of Type AB within the migraine diagnostic sroup as compared with a sample of muscle contraction headache sufferers. For many years, practitioners treating headache eufferera made note of the "mieraine personelity." This clinical lore developed in the absence of any empirical demonatration of the phenomenon. Indeed, a review of the literature examinine the personality characterigtics of migralneurs prov1ded equivocel results.

After close examination of the desoriptions provided by practitioners. 1t was hypothesized that what was belns noted was not "personality" or characteristics of psychopathology. per se, but 1nstead, the high incidence of Type As within this population of vapcular headache individuals. Although two previous atudies had provided some evidence of a glanificant relation between headache occurence and the TABP within a general population (H1cks \& Campbell, 1983: Woods et al., 1984), no prospectlve study to date had documented this relation. 


\author{
Regulta from the chl-gquape analyate in this \\ Investisetion clearly support the primery hypothesis: \\ a Eisnificentiy lariter proportion of MGe were \\ elaselfted as Type $A$ by the JAS. Indegd. over $53 \%$ of \\ the MGs scowed between the 75 th and 99 th pexcentile on \\ the JAS Type A acale, a congervative meagure of TABP. \\ This hish Incidence sate la clearly a phenomenon found \\ only in the vasculax headache gample. In the MC \\ sample, leas than $25 x$ of headache sufferers acored in \\ th1e upper quartile. \\ Examination of the lower quartiles of the headache \\ population 111ustrate a differential alstribution as \\ we11. Whereas a third of the MCs were clasiffied as \\ Type B (1.0.. 33.33\% of MCe ecored at the $25 \mathrm{th}$ \\ percentile or lower). only $16.66 \%$ of MGs scored In this \\ lowest quartile. \\ It 18 Important to note thet the Importance of \\ this elndina now allowe the broadening of the concept \\ of TABP. AB originaliy formulated by cardiologiata \\ Rogenman and Friedman, Individuals possessins \\ charactertatica of Type A were at risk to develop \\ cardiovascular disease. Subsequent to their original \\ conception, nearly all of the research has focuged on a \\ single population. That 18, all large investigations \\ of the TABP have pevolved around those individuals at \\ risk of developing coronary artery disease. With this
}




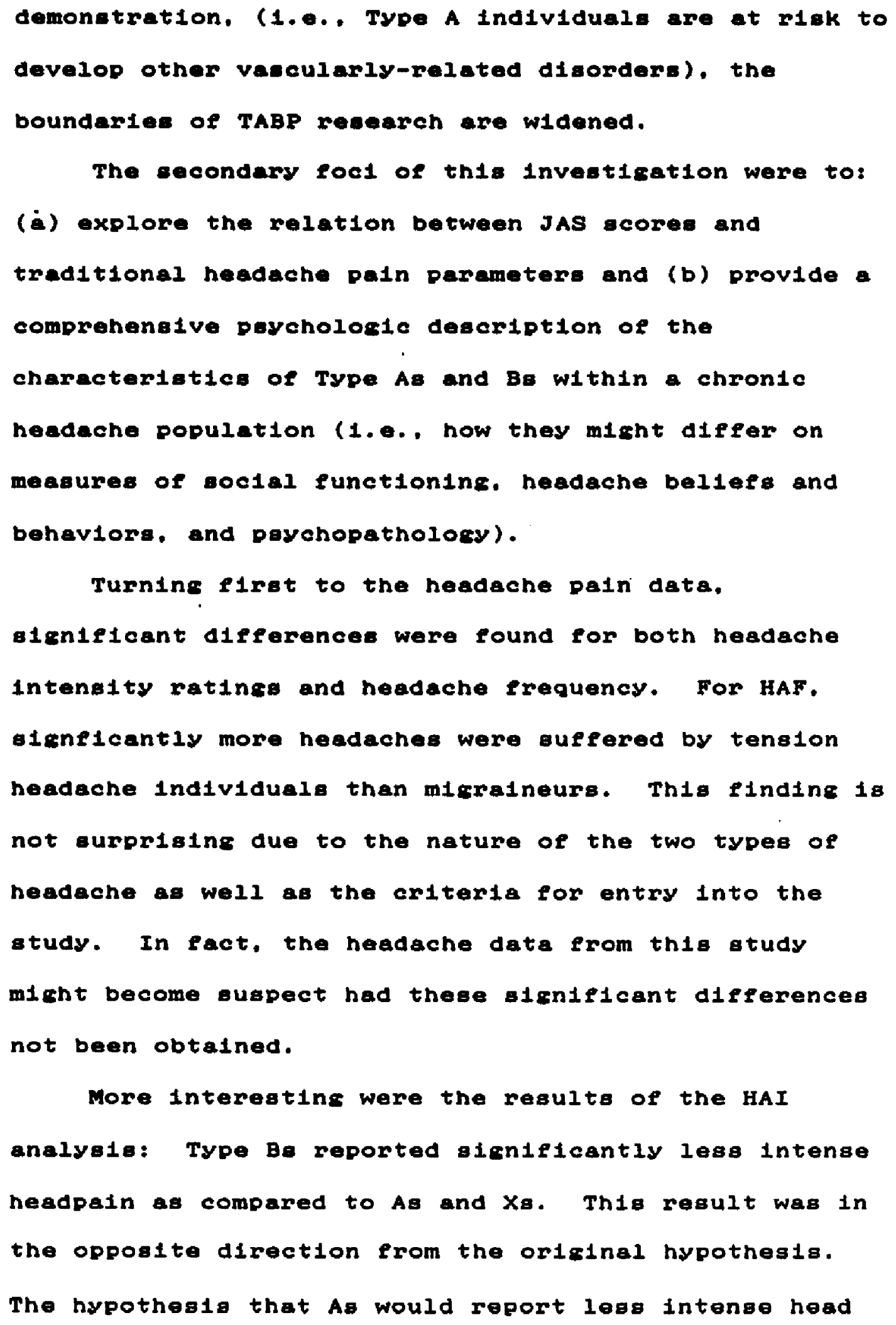


pain than Be srew out of the laboratory flndinge that Type As tend to auppresa the reporting of physical compleinte and aymptome. Th1s elrat attempt to generalize these findings outbide of the laboratory has falled. Theae Inftial resulta need to be replicated In Puture studies.

Also of note 18 the result that sisnificantly different intenelty ratinge were not obtalned between muscle contrection headache subjects and migralneurs. It 1s usualiy assumed that migraine headache at acks, due to thetr vascular nature and assoclated symptoms. are the more painful. This lack of findings invites further empirical Inveatigation.

Several hypotheses were sugsested as secondary goals of this Investigation. Each was concerned with providing a description of Types $A$ and $B$ headache sufferers within a particular domain of paychological functioning.

A controversy within the Type A literature Involves the relation between measures of the TABP and paychopathology. Irvine and associates published results which demostrated a strong correlation between the two constructs (Irvine et al., 1982), concluding that Type A was prychopathology. Althourh some researchers (Irvine et al., 1982) have attempted to demonstrate that the TABP 18 a constellation of 
traditional conetructs of peychopathology. others (Chesney et al., 1981; Wadden et al.. 1983) have demonatrated that the TABP does not stronely correlate with measures of peychologic disturbance in various populations. To date, no Investigation was conducted within a chrontc headache population.

Consistent results were obtalned within this study for all measures of psychopethology (1.e.. MMPI, STAI, and zuns). It was hypothesized that messures of paychopathology would not be related to JAS scores. Th1s study was euccesseul in demonetrating that within a chronic headeche population, measures of Type.A are not oleniflcantly related to measures of peychopathology. Reaulta from atatical analyses of MMPI, STAI and zung data revealed no glgnificant differences between those headache volunteers classified as Type A, B, or $X$.

These IIndings have several Important Implications. First, from a treatment viewpolnt. traditional intervention procedures used to modify levele of depresalon, anxlety, paranola, or other peychologlcal disturbences will have little effect on Type A behavior per se. Additionally, because of the lack of Blonificant statiotical differences between As and $\mathrm{Bg}$ on these measures, obtalned differences between 
these groups on others meseures cennot be accounted for by differences in levels of paychopethology. Tumnins to the eolal funetionins data, 1t was hypothesized that Type A and $B$ headeche sufferers would differ on meesures of assertion, social avoldance and fear of nesetive evaluation. Regultg within this domain are lese conelatent than above and more difficult to interpret.

Concerning the Aseretion Inventory data, there were no alentflcant differences between headache diagnostic eroups nor JAs claselfications. As well. the atatioticel analyaes revealed no differences for FNE data. However, the Interaction effect was sionificant for SAD data, with poet-hoc analyges revealins that for Type Bs only, muscle contraction headache eufferera acored algniflcantly higher than mieratneurs.' See Plaure 1.

The SAD was developed and validated as a measure of goctal avoldance. Thoge Individualg gcortho htgh (usually above 9 ) on this Bcale tend to avold soctal Interactions, prefer to work alone, report that they talk less, and worry about soclal relationships; Type $B$ tension headache sufferers gcored above this cutoff score (M $=13.85)$ with their mieraine counterparta gcorins glanficantly lower ( $M=2.04$ ). Unfortunately. 1t 1 unclear how to interpret this finding: there $1 \mathrm{~s}$ 
no current exieting litereture which would predict this outcome. It 18 hoped that replication of this study w11l provide additionel information in order to underetand this result.

The lack of consistent results within the social functioning domain is disappointing. As noted earlier, th1s area currently seems to be the most active with several very recent Investigations demonstrating differences between Type $A$ and $B$ college students on levela of goctal skill (Watkins, 1986; Watkins \& Elsler, 1986). Both of these studies, using behavioral assessment of social skill, revealed clear differences between $A B$ and Be. One explanation for the Inconsietency between this Investigation and others may 11e in the assessment technique used. In this gtudy. questionnalre or self-report data was the only source of Information whereas the previous studies used a behavioral asseament methodology. It 1s posalble that while social skill differences do exist between Type $A$ and $B$ Individuals, these differences are not exhibited on questionnalres designed to measure assertion, social avoldance, and fear of negative evaluation. Future studies need to continue to Invegtigate this area with both gelf-report and behavioral asgessments of social skill. 
One of the three questionneires ueed to describe the health beliefo and beheviose of headache sufferems Typed A. B, or $X$, the Health Locus of Control, did not gtatiaticaliy differentiate between the eroups.

However. as hypothesized, sisnificant differencea were obtalned for the other two measures, the IIInese Behavior Questionnalpe and the IIIness Behavior Inventory.

On the IBI. Btatiatical difterences were obtained between Typer $A$ and $B$. with Type Be evidencins hisher acores then Type AB. Normative data for the IBI report 72.5 for patienta labeled as hish 11ineas behavior patients and 53.7 for low 111 ness behavior patients. The meane for AB $(55.47)$ and $B$ e (72.50) colncide quite closely with the normetive deta; therefore obtalned diferences are not merely statiaticaliy different but In comparison to normative data, they become quite meaningeul.

These data are rather atriking because they reflect substantial differences between Type $A$ and $B$ headache Individuale along 11 inege behavior parameters. Because the IBI was developed to identify patients with excessive or Inappropriate 111 ness behavior. and scores on this questionnalre correlate positively with medical expenditures. erequency of medical utilization. number of days in the hospltal, and other aimilar Indices 
(Turkat \& Pettegrew, 1983), obtained resulta confirm the notion that Type As poseese lower rates of 111 negs behaviors than their Type B counterparta. But as noted by Eagleston et al. (1986) there 1s the possibility that Type Ag may not actually exhlbit lesg 11lness behavior but merely report this difference. In future Investigations concerned with 111 ness behavior differences between $A B$ and $B B$, researohers need to obtaln additional valid measures of 1linesa behavior (eg.. hoepltal and doctor recorda. medication indices). Statiatical differences were also obtained between migralne and muscle contrection headache sufferers on the Illness Behavior Inventory. Results demonstrated that migralneurs cored higher on the IBI than tension headache volunteers. Although sroup means were significant. they did not colncide as well with normative data as did the Type A-B differentiation. Th1s effect, although 1mportant to document, is not surprla1ng. The physical eymptoms which commonly accompany migraine headache attacks are usually aubatantialis incapacitating so that Individuals usually exhiblt those behaviors measured by the IBI (1.e. consultation with a physician, taking medication. substantial interference with daliy functioning while 111). 
Two of the sceles from the Illness Behevior Questionnalwe differentiated between Type $A$ and $B$ headache eubjecta. Statietical analyaes revealed differences between Type $A$ and $B$ headeche sufferexs on the Whiteley fypochondriagis Seale of the IBQ as well as Scale 3. Paychologle versus Somatic perception of 11Inese. Specifically, As scored hisher ( $M=1.6$ ) than $\mathrm{Bg}(\underline{M}=.75)$ on Scale 3 with As (M-2.58) scoring lowar than $x=$ or $B=(M=-4.73$ and 4.13 , reapective1y) on the Whiteley Hypochondriagis Scale.

The Whiteley scale was developed to digtingulah patiente who exhiblted high levele of hypochondriacal behavior from thoae Individuala with normal levela. Accordins to the scale's developers, a high acore Indicates "somatic preoccupation, dieease affirmetion. disease phobla. and Indicates the Increased probability of a hypochondriacal disorder" (P1lowgky a spence. 1984. p. 125). Scala 3 of the IBQ (PBychologic va. Somatic perception of 111nera) Indicater the degree to which the patient percelves the 111ness in "paychologic" ag opposed to "phyalologlc" terma. These differences are consigtent with the notion that Type A Individuala eall to perceive phyalcal gymptoms and thus chrontcally overexpose themselves to stregeore (Burke 8 We1r, 1980; Hert, 1983). In a recently published report. Eagleston and hls colleagues 


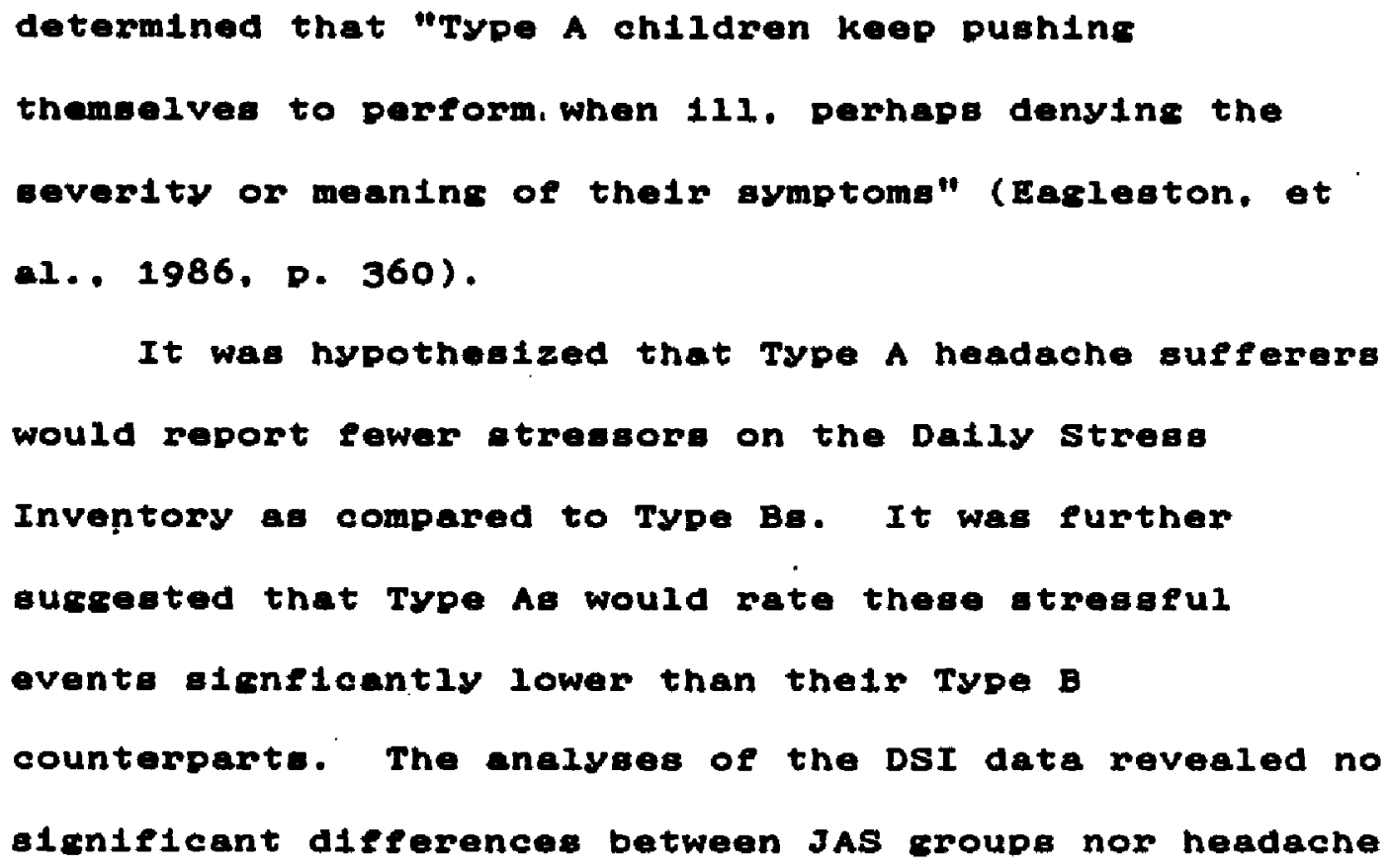




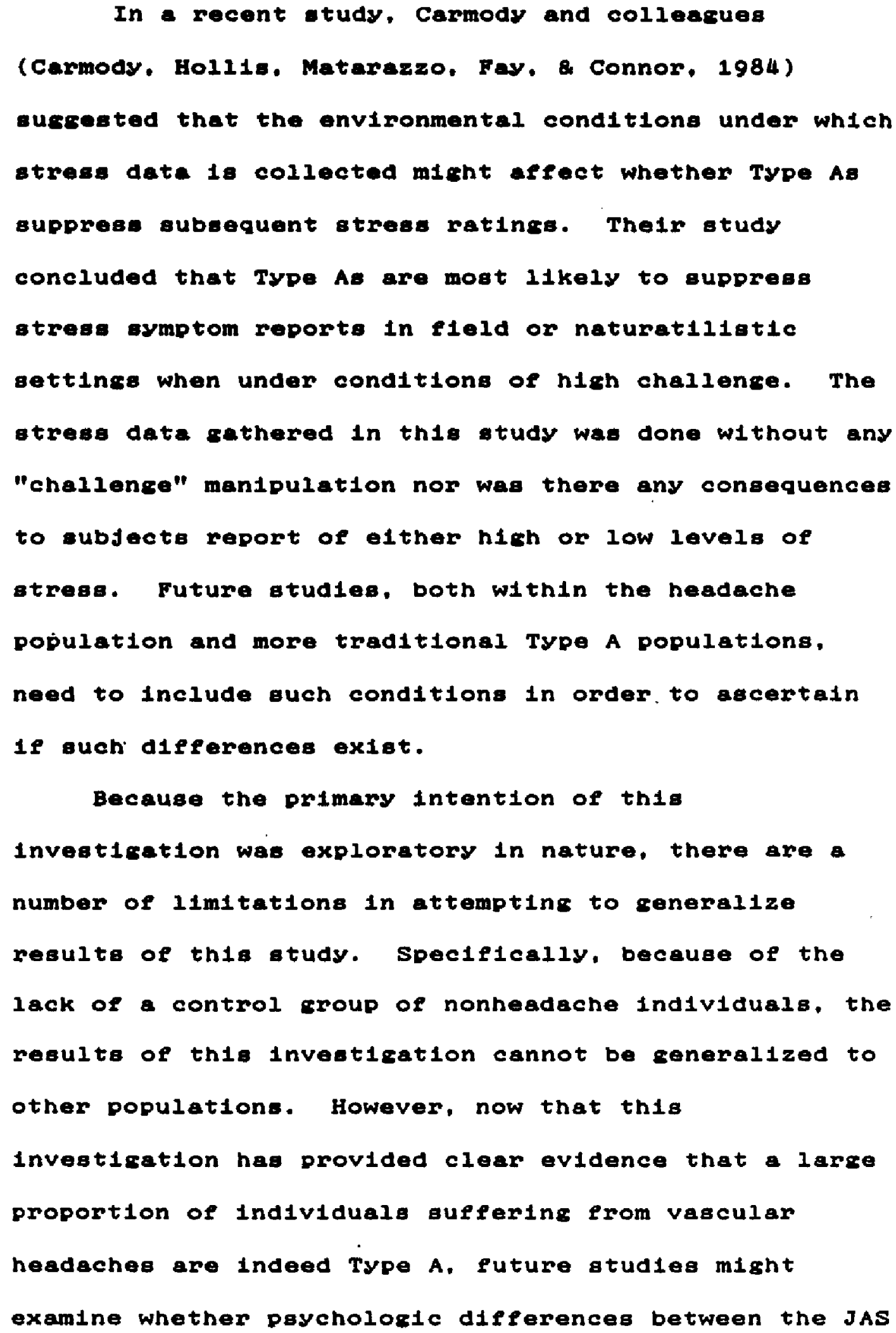


TABP and Headache 94

sroupa here are also encountered in more traditional Type A populations. This Investigation clearly openg the door for that direction of atudy.

Although geveral paychologlcal queationnalreg were used In this etudy to provide a comprehensive description, the Investigation by no means encompassed all constructe within paycholopathology. social functionins, health bellefs and behaviors, etc. As well, thie Investigation used only one measure of each paycholosical conatruct. It w1ll be important in future studies to use not only different questionnalres but different procedures to measure certaln constructa (e.s., behavioral assessment of aseertion, actual 1lineas behaviora).

Additional atudies are needed to replicate the findinge obtalned here and to further expand our knowledge of the ways in whlch Type As and Be function. As mentioned earlier, actual thle study falled to demonstrate significant differences between Types $A$ and B on three measures of social functioning. the asgessment of social skill levels among Type A and $B$ Individuals is an empirical question ripe for Investigation (Watk1ns, 1986: Watkins \& E1sler, 1986). As well, current Invertigations point to the Importance of anger and hostility levels as mediators in the development of CHD In Type A Individuala (Mathewg \& 
TABP and Headache 95

Haynes, 1986). When this research 1s performed, 1t w111 be Important however to Include not only traditional Type A populations (1.e.. those at risk for CHD) but other populations like this one, as well. In spite of the limitations noted above. the findinge obtalned in this effort are encouraging. In summary. this Investigation was auccessful in several spheres. Firat, this gtudy provides a clear demonstration that the traditional conceptualization of the TABP need to be expanded. Th1s to based on the high Incidence of Type A Individuale within the vascular headache eroup. What was inftially referred to as "coronary-prone behavior" Instead needa reconceptualized as "vascular-prone behavior." In addition. this etudy provides clear evidence that the "migraine personality" which headeche practitioners have written about for years without any empirical evidence may in fact be the ame constellation of characteristica referred to as the Type A Behavior Pattern. Besides a replication of the findings of this gtudy, future Investigations need to begin to examine the blological mechanisms which link Type A behavior to migraine headache.

In addition, this investigation was successful in describing the paychological functioning of Type $A$ and B headache sufferers across several domains. Some of 
TABP and Headache 96

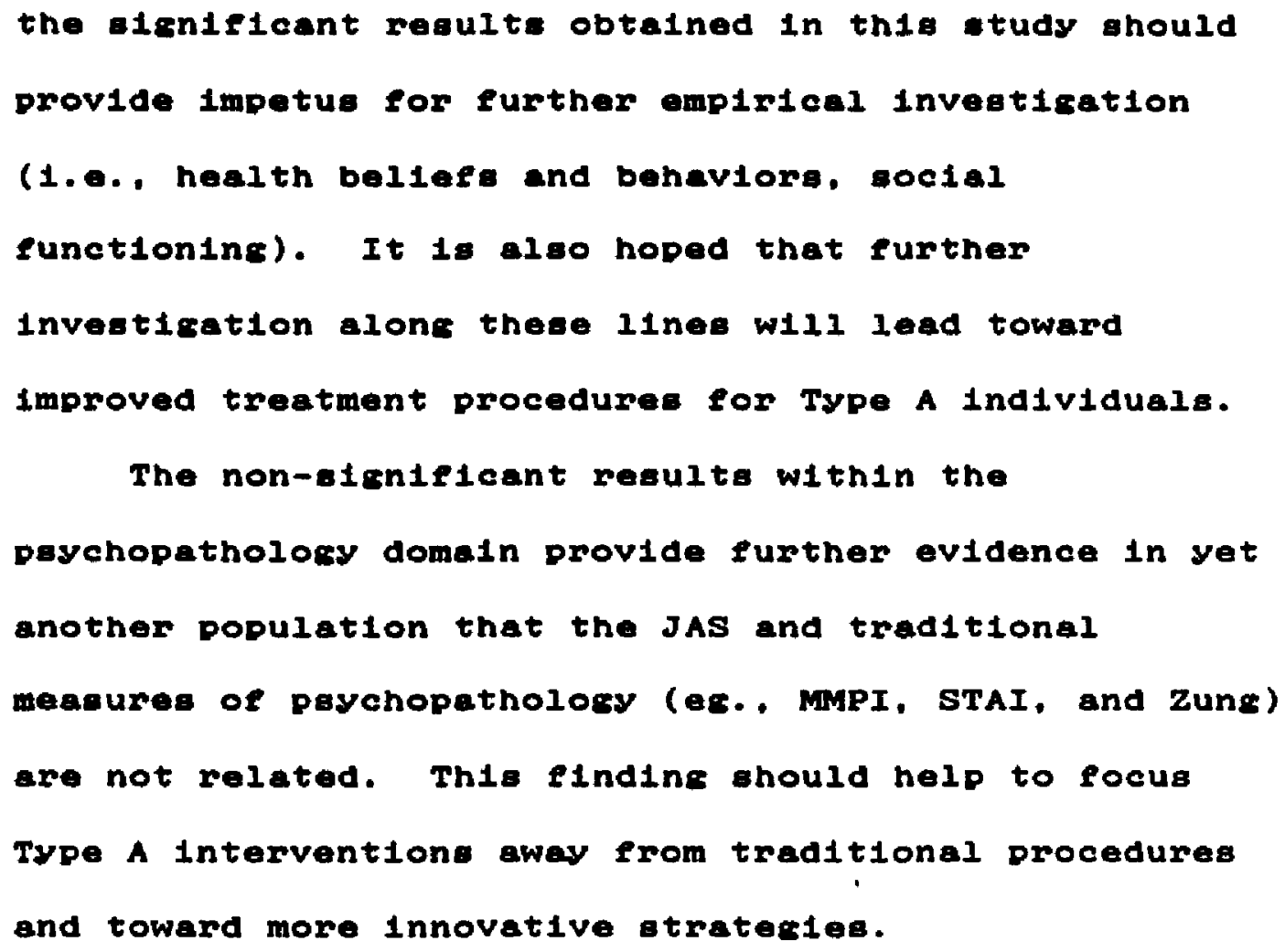


TABP and Headache

\section{REPERENCES}

Adama, H. E., Feuerateln, M., E Fowler, J. L. (1980). The migraine headache: A review of parametere, theor1es, and 1nterventions. Psycholorieal

Bu11et1n. 87. 217-237.

Ad Hoc Committee on clabelfleation of headeche.

(1962). Claesiflcation of headeche. Journal of the Amertoan Medical AsBoctetion. 179. 717-718. Andras1k, F., Blanchard, E. B.. Arena. J. B., Saunders, H. L.. \& Barron, K. D. (1982). Paychophystoloey of recurrent headache: methodological 1 gaves and new empirical f1ndings, Behavior Therapy. 13, $407-429$.

Andras1k, F.. Blanchard, E. B.. Arena, J. G.. Teders, S. J.. Teevan, R. C., and Rodlchok, L. D. (1982). Paychological functioning in headache sufferers. Payohosomat1e Med1c1ne, 44., 171-182. Andras1k, F., Blanchard, E. B., Arena, J. G., Teders, S. J., R Rodichok. L. D. (1982), A erose validation of the Kudrow-Sutkus clasification aystem for diagnoaing headache type. Headache. 22. 2-5.

Appenzellar, 0. (1969), Vacomotor function in misraine. Headache. 2. 147-155.

Appenzelier, O.. Feldman, R. G.. B Frledman, A. P. (1979). Migraine headache and related conditions: panel 7. Archtves of Neurology. 36. 784-805. 
Bakal, D. A. (1975). Headache: A blopaycholostoal perspective. Paychologleal Bulletin. 82. 369-382.

Beeson. P. B.. McDermott, W.. \& Wyngaarden, J. B. (1979). Cec11's Textbook of Medioine. PhIladelphia: W.B. Saunders Company.

Berkman, L. F. \& Syme, L. (1979), Soclal networka, host resistance, and mortality: A 9 year follow-up atudy of Alameda county residents. Amertcen Journal of Ep1dem1010\%y, 109, 186-204. Blumenthal, J. A., Wllliams, R. B., Kong, Y.. Schanbers, S. M. \& Thompeon, L. (1978). Type A behavior pattern and coronary atherosclerogis. C1rculation. 58, 634-639.

Bortner, R, W. (1969), A short rating ecale as a potential measure of pattern A behavior. Journal of Chronte D1sesges. 22. 87-91.

Brand, R. J. (1978). An examination of the association between $A-B$ behavior and coronary heart disease Incidence. In T.M. Dembrosk1. S.M. Welss, J.L. Shlelda, S.G. Haynes, \& M. Felnielb (Eds.). Coronary-prone behavior. New York: Springer-Verlag.

Brand, R. J.. Rosenman, R. H., Sholtz, R. I.. \& Friedman, M. (1976). Multivariate prediction of coronary heart disease in the Western Collaborative Group study compared to the findings of the Framingham study. C1rculation. 53. 
Brantley, P. J., Wagroner, C. D.. Jones, G. N.. A

Reppaport, N. B. (In prese). A dally Btress

Inventory: development, wellabllity and validity.

Journal of Behaviorel Medicine.

Burke. R. J. B We1r. T. (1980). Career auccese and personal faliure: nature of the problem.

Industrial Reletione, 27, 7-17.

Caffrey, B. (1968). Reliability and validity of

peraonality and behavioral measures in a atudy of

coronary heart disease. Journel of Chrontc

D1eepese. 21. 191-204.

Carmody. T.. Holl1a, J.. Matarazzo, J.. Fay., S. 8

Connor. W. (1984). Typé A behavior, attentional

Btyle. and eymptom reporting amons adult men and

women. Health Peycholory. 3. 45-61.

Carver, C.. Coleman, A. E., 2 G1asa, D. C. (1976).

The coronary-prone behavior pattern and the

guppresion of fatigue on a treadmill test.

Journal of Pergonality and Sociel Paycholory.

$33(4) .460-466$.

Carver, C. and Glass, D. (1978). Coronary-prone behavior pattern and Interpersonal ageresiton.

Journal of Pergonelity and Soc1al Paychology. 36. $361-366$

Chesney. M. S. Black. G. W. Chadwick, J. H.. \&

Rogengman, R. H. (1981). Paychological

correlateg of the Type A behavior pattern.

Journal of Behevioral Medicine. 2. 217-219. 
Cinciripint, P. M., Williamaon, D. A., and Epatein, L. H. (1980). Behavioral treatment of migraine headache. In J.M. Fersuson \& C.B. Taylor (Eds.). The Comprehenstve Handbook of Behavioral Medicine (Vol. 2). Jama1ca, N.Y.: Spectrum Press. Clark, D. H.. Hough, B., \& Wolff, H. G. (1936). Experimental etudies on headache: observations on histamine headache. Archives of Neurolory and Paychletry. 35. 1054-1069.

Cobb. s. (1976). Soc1al support as a moderator of 11fe atresa. Peychosomet1c Med1c1ne. 38. 300-313. Cohen, J. B.. Syme, S. L., Jenk1ns, C. D., Dagan, A., \& zyzansk1. S. J. (1975). The cultural context of Type A behavior and the risk of CHD. American Journal of Epldemiolory. 102. 434.

Cohen. M. J., \& MoArthur, D. L. (1981).

clasaffication of mieraine and tension headache from a curvey of 10.000 headache diaries.

Headache. 21. 25-29.

Cuypers. J.. Altenkirch, H.. and Bunge, S. (1981). Personality profiles in cluster headaches and migraine. Headache, 21. 21-24.

Dalessio, D. J. (1972). Wolf.'s Headeche and other Head Pain. (3rd Ed.). London: Oxford University Presa. 
Dembrosk1, T. M., MacDougall, J. M., Herd, J. A., and Shlelds, J. M. (1978). Eftect of level of challenge on pressor and heart rate responses in Type $A$ and $B$ aubjects. Jounnal of Applied Soc1el Paychology. 2. 209-228.

Dembrosk1, T. M., MacDougall, J. M., $\operatorname{sh} 1$ eldB, J. L., Pett1to, J.. and Lushene, R. (1978). Components of the Type A coronary-prone behavior pattern and cardlovascular responses to paychomotor performance challence. Journal of Behevioral

Med1c1ne. 1. 159-176.

Dembrosk1, T. M., MacDougall, J. M., W1ll1ams, R. B., Haney, T. L., \& Blumenthal, J. A. (1985). Components of Type A, hostility, and anger-1n: Relationahip to anglographic findings. Peychosometic Medicine. 47. 219-223.

Dlamond, S. and Daleas1o, D. J. (1978). The Practicing Physician'B Approach to Headeche (2nd Edition). Baltimore: Williams \& Willkins. Ducimetiere, P.. Cambien, F., Richard, J. L. . Rakotovao, T., \& claude, J. R. (1980). Coronary heart disease in middle-aged Frenchmen. Lancet. 1. $1346 \rightarrow 1349$.

Dukes, H. T. \& V1eth, R. G. (1964). Cerebral anterlography during migraine prodrome and headache. Neurology, 14, 636 . 
TABP and Headache 102

Easleston, J. R., K1rmil-Gray, K., Thoresen, C, E., Wiedenfeld. S. A.. Breoke, P., Heft, L. \& Arnow, B. (1986). Phyalcal health correlates of Type A Behavior In children and adolescents. Journal of Behevioral Medicine, 2. 341-362.

Eastwood, M. R.. and Trevelyan, H. (1971). Stress and coronary heart disease. Journal of Paychosomatic - Research. 15. 289-292.

Eysenck, H. J.. \& Fulker, D. (1983). The components of Type A behaviour and 1ts senetic determinants. Personelity and Individual Difeerences. 4. 499-505.

Feinleib. M.. Brand, R. J.. Remington, R., \& Zyzansk1. S. J. (1978). Section summary: Association of the coronary-prone behavior pattern and coronary heart disease. In T.M. Dembroski, S.M. We18в. J.L. Shlelds, S.G. Haynes, \& M. Felnlelb (Eds.), Coronary-prone behav1or. New York:

Springer-Verlag, 2-9.

Friedman, A. P. (1978). Migralne. Medical Clinics of North Amer1ca. 62. 481-494.

Friedman, A. P. (1979). Characteristics of tension headache: a proplle of 1420 cases. Paychosomat1ce; 20. 451-461.

Frledman, M. (1969). Pathogeneg1s of Coronary Artery

D1sease. McGraw-H111: New York.

Frledman, M., Byers, S. O.. Dlamant, J., \& Rogenman, R. H. (1975). Plasma catecholamine response of 
TABP and Headache. 103

coronary-prone aubjecte (Type A) to a epec1f1c

challenge. Metaboliem. 24(2), 205-210.

Frledman, M., Byers, s. O., Romenman, R. H., \&

Elevitoh, F. R. (1970). Coronary-prone

Individuals (Type A behavior pattern): Some

blochemlcal characterlotics. Journal of the

American Medicel Asgociation, 21. 1030-1037.

Frledman, M., \& Rosenman, R. H. (1959). Association

of epecific overt behavior pattern with blood and

cardivascular findings. Journal of the Amerlcan

Madical Alsociation, 169, 1286-1296.

Frledman, M. R Rosenman, R. H. (1974). Type A

Behavior and your Heart. New York: Knopf.

Frtedman, M., St. George, S., Byers, S. O. (1960).

Excretion of catecholamines, 17-ketosterolds,

17-hydroxy-corticolds and 5-hydroxylndole in men

exhibiting a particular behavior pattern (A)

assoclated with high Incldence of clinical

coronary artery disease. Journal of Clinical

Invest1rations. 39. 758-764.

Friedman, M., Straus, R., Wurm. M., \& Kositchek, R.

(1968). The relationghip of behavior pattern A to

the atate of the coronary vasculature: a study of

51 autopsied subjects. Americen Journel of

Medicine. 44, 525-538. 
TABP and Headache 104

Gambri11, E. D. \& Richey, C. A. (1975). An ageertion Inventory for use in assessment and research. Behavior Therepy. 6. 550-561.

Gilbert. D. G., \& Reynolda, J. H. (1984). Type A Pereonality: Correlations with personality variables and nonverbal emotional expressions during interpersonal competition. Personality and Individual Differences. 5, 27-34.

Glass. D. C. (1977). Streas behavior patterns and coronary disease. American Sclent1st. 65.

$177-187$.

Glas8. D. C. (1977). Behavior Pettern, StregB, and Coronary Disease. H11lsdale, N.J.: Erlbaum. Gordon, T., Garcia-Palmier1, M. R.. Kasan, A., Kannel. W. B.. \& Schifeman, J. (1974). Differences in coronary heart disesese in Framingham. Honolulu, and Puerto Rico. Journal of Chronle D18eases. 27. 329-337.

Graham, J. R. \& Wolfe, H. G. (1938). The mechantam of migraine headache and the action of ergotamine tartrate. Archives of Neurolory and Pgychlatry. 39. 737-763.

Harrison, R. (1975). Paychologtcal testing in heedache: a review. Headache. 15. 453-463. Hart, K. E. (1983). Physical symptom reporting and health perception among Type $A$ and $B$ collece males. Journel of Humen Stress $, 2,17-22$. 


\section{TABP and Headache 105}

Haynes. S. B.. Feinlelb, M., Levine. S., Scotch, N., \& Kennel, W. B. (1978). The relationsh1p of

paychosocial factors to coronary heart disease in the Framingham Study: prevalence of coronary heart d1sease. Amertcan Journal of Ep1demiolory, 107. $384-402$.

Haynes, S. G.. Felnleib, M., Kannel, W. B. (1980). The relationehip of peychosocial factore to coronary heart digease in the Framingham study. III. E1ght-year Incidence of coronary heart d1sease. American Journal of Ep1demiolory. 111. $37-58$.

Henryk-Gutt, R. and Rees, W. L. (1973). Psychologlcal aspects of migraine. Journel of PBychosomatic Research, 17, 141-153.

H1Ck:, R. A. \& Campbell, J. (1983). Type A-B behavior and self-estimates of the frequency of headaches in college students. Psycholorical Reporte. 52. 912 .

Irvine. J.. Lyle, R., and Allon, R. (1982). Type A personality as paychopathology. Journal of Paychosomat1c ReBearch. 26, 183-189.

Jenkins, C. D. (1971). Paychologic and social precursorg of coronary disease. New York Journal of Medicine, 284, 244-255, 307-317.

Jenk1ns, C. D. (1976). Recent evidence supporting paychologic and social rigk factora for coronary 
d1sease. Now Enrland Journal of Medicine, 294. $987-994,1033-1038$.

Jenkine, C. D., Rosenman, R. H., E Friedman, M. (1965). Repllcability of reting the coronary-prone behavior pattern. Britieh Journal of Preventive and Social Medicine. 27. 424-434. Jenk1ns, C. D.. Rosenmen, R. H., Zyzanski, S. J. (1974). Prediction of clinical coronary heart disease by a test for the coronary-prone behavioral pattern. Now Enrland Journal of Medicine. 290. 1271-1275.

Jenk1ne, C. D., Zyzansk1, S. J., R Rosenman, R. H. (1976). Risk of new myocerdial infarction in middle-aged men with manlfest coronary heart disease. Circulation, 53, 342-347. Jenk1nB, C. D. Zyzanski, S. J., and Rosenman, R. H. (1979). Manual for the Jenking Activity Survey. New York: Paycholosical Corporation. Jenkine, C. D., Zyzanski, S. J., Rosenmen, R. H. , \& Cleveland. G. (1971). Assoclation of coronary-prone behavior scores with recurrence of coronary heart disease. Journal of Chronte D1eeaseg, 24. $601-611$.

Kannel. W. B.. \& Gordon, T. (1974). The Framingham Study. DHEW Publication (NIH) 74-599. Washington, D.C.: U.S. Government Printing offlce.

Ke1th, R. A.. Lown, B., \& Stare, F. J. (1965). Coronary heart disease and behavior patterns: an 
examination of method. Paychosomatic Mediclne.

27. $424-434$

Keye, A., Arevania, C., Blackburn, H., Vanbuchem. F. S. P.. Buzina, R., DJordjenic, B. S.. Fidanza, F.. Karvonen, M. J.. Menott1, A., Puddu, V., \& Taylor, H. L. (1972). Probability of middle-aged men developins coronary heart disease in. 5 years. C1roulation, 45, 815-828.

Kozarevic, D., Pirc, B., Ravic, Z., Dawber, T. R.. Gordon, T., \& zukel, W. J. (1976). The Yugoslavia cardiovascular disease study. Part II: factors in the Incldence of coronary heart disease. Amertican Journal of Epidemiolory. 104. 133-140.

Kudrow, L. (1978), Current aspects of migraine headache. Paychosometice. 19. 48-57.

Kudrow, L. and Sutkus, B. J. (1979). MMPI pattern spectfletty in primary headache disordera. Headache. $19,18-24$.

Levenkron, J. C., Cohen, J. D., Mueller, H. S., \& Figher, E. B. (1983). Modifying the Type A coronary-prone behavior pattern. Journal of Consultins and Clinical Paycholory, 51, 192-204. Loval10, W: R, and P1ghk1n, V. (1980). A psychophysiological comprison of Type A and $B$ men exposed to fallure and uncontrollable nolie. Paychophysiology, 17, 29-36. 
TABP and Headache 108

MacDougal1, J. M.. Dembrosk1, T. M., M Muante, L. (1979). The etructured Interview and questionnalre methode of aseeselns coronary-prone behavior In male and female coljese atudent. Journal of Behavioral Medicine. … 71-84.

Manuck, s. B.. Craft, S., 8 Gold, J. (1978). Coronary prone behavior pattern and cardiovascular response. Paychophys1010yy. 15. 403-411.

Manuck, S. B. \& Garlend, F. N. (1979). Coronary prone behavior pattern, task Incentive, and cerdiovagcular response. Paychophysiolory. 16. 135-142.

Matthews, K. A. (1982). Psychological perspectives on the Type A behavior pattern. Paychological Bullet1n. 91. 291-323.

Matthewe, K. A. \& Carra, J. (1982). Suppression of menstrual distresa aymptoms: a study of Type A behavior. Pergonality and Soc1el Peycholory

Bulietin. $\underline{8}, 146-151$.

Matthews, K. A. \& Haynes, S. G. (1986). Type A behavior pattern and coronary disease risk: update and critical evaluation. American Journal of Ep1demiolory. 123. 923-960.

Nowack, K. Seseenrath, J. (1980). Coronary-prone behavior. locus of control and anxiety. Paycholorical Reporta. 47. 359-364. 
O'Brien. M. D. (1971). Cerebral blood flow changes in the migralne headache. Headeche. 10, 139-143. Olton. D. S., A Noonbers. A. R. (1980). Blofeedbeck: clintcal applications in behavioral medicine. Enslewood Cliffa, N.J.: Prentlce Hall. Ph111p8, C. (1976). Headache and personality. Journal of Psychosomatic Reserach, 20. 535-542. Pllowsky. I. 8 spence, N. D. (1983). Manuel for the IBQ (eecond edition).

Raskin, N. H., A Appenzelier, O. (1980). Headache. In L.H. Smith, Jr. (Ed), Major problems in Internal medicine (vol 19). Philadelphia: W. B. Seunders.

Rogado. A. Z. Harrison, R, H., \& Graham, J. R. (1974). Personality profilea In clugter headache. migralne, and normal controls. Archives of Neurob1010.y. 37, 227-241.

Rosenmen. R. H. (1978). The interview method of assessment of the coronary-prone behavior pattern. In T.M. Dembrosk1, S.M. We1ss, J.L. She1lds, S.G. Haynes, a M. Felnlelb (Eds.), Coronary-Prone Behavior. New York: Springer-Verlag. Rosenman, R. H., Brand, R. J., Jenkins, C. D., Friedman. M., Straus, R., and Wurm, M. (1975). Coronary heart alsease in the Western Collaborative Group Study: final follow-up expertence of 8.5 yearg. 
Journal of the Amerloan Medical Apeocletion, 233. $872-877$.

Rosenman, R. H. Brand, R. J.. Sholtz, R. I., \&

Friedman, M. (1976). Multivariate prediction of coronary heart disease during 8.5 year pollow-up In the Western Collaborative Group study. Americen Journal of Cerdiology. 37. 903-910. Rosenman, R. H. \& Chesney, M. A. (1980), The relationsh1p of the Type A behavior pattern to coronary heart disease. Activitas Nervosa Superior, 22, 1-45.

Rosenman, R. H. \& Frledman, M. (1961). Agsociation of a specific overt behavior pattern in females with blood and cardiovascular findings. Clrculation. 24. 1173-1184.

Rosenman, R. H., Frledman, M.. Jenk1nB, C. D.. Straus, R. Wurm, M., \& Kositchek, R. (1967). Recurring and fatal myocardial infarction in the Western Collaborative Group study. American Journal of Card1010\%y, 19. 771-775.

Rosenman, R. H., Friedman, M., Straug, R., Jenkins, C. D., Zyzansk1, S. J.. and Wurm, M. (1970). Coronary heart disease in the Western Collaborative Group Study: A follow-up experience of 4.5 years. Journal of Chronte D1seases. 23. 173-190.

Rosenmen, R. H., Friedman, M.. Straus, R.. Wurm. M.. Kogltchek, R. Hahn, W., and Werthessen, N. T. 
A predictive atudy of coronary heart disease: The Western Collaborative Group study, Journel of the Americen Medical Association, 189, 15-22.

Rosk1es, E., Kearney, H, Spevack, M., Surk18, A.. Cohen, C.. G Giman, s. (1979). Generalizability and durablilty of treatment effecta in an Intervention program for coronary-prone (TyDe A) manasers. Journal of Behavioral Mediclne. 2. 195-207.

Rogk1e日, E., Spevack, M., Surk1., A., Cohen, C., \& Gilman, S. (1978). Changing the coronary-prone (Type A) behavior pattern in a nonclinical population. Journal of Behavioral Mediclne, 1 . 201-216.

Scherw1tz, L., Berton, K., \& Leventhal, H. (1978). Type A eseessment and Interection in the behavior pattern Interview. Poychosometic Medicine, 39. $229-240$.

Schucker, B. \& Jacobs, J. R. (1977). ABsessment of behavioral risk for coronary diseage by volce characterlatics. Psychosomat1c Medicine, 39. 219-228.

sicuter1. F. (1967). Vasoneuroreactive substances and thelr Implicationa in vascular pain. In A.P. Friedman (Ed.), Research and clinical studies of headache. Baltimore: Williams \& Wikeng.

S1gler. L. H. (1959). The mortaltty from arteriosclerotic and hypertensive heart diseases In the United States. Part I: possible relation 
distribution of population and economic etatus. Americen Journal of Cardiolory. 1. 605.

Sparacino. J. (1979). The Type A behavior pattern: a critical aseasement. Journal of Human Stresg. 5. 37-51.

Speliberger, C. D., Gorsuch, R. L., \& Lushene, R. E. (1970). The manual for the STAI. Palo Alto: Congulting Paychologiata Presa. Inc.

Su1nn, R. M., Bloom, L. J. (1978). Anxiety manasement training for pattern A behavior. Journal of Behavioral Medictne, 1, 25-35.

Thurman, C. W. (1985). Effectiveness of cosnitive-behavioral treatments in reducing Type A behavior among university faculty. Jounnal of Coungeling Psychology. 32. 74-83.

Thurstone, L. L. (1953). Thurstone Temperament Schedule. Science Research Associates: Chicago. Tun1s, M. M. and Wolff, H. G. (1952). Analys18 of cranial artery pulge waves in patiente with vascular headache of the migraine type. American Journal of Medical Science. 224, 565-568.

Turkat. I. D. \& Pettegrew, L. D. (1984). Development and validation of the Illness Behavior Inventory. Journal of Behavioral Agaesament. 5. 35-47.

Wadden, T. A., Anderton, C. H., Foster, G. D., \& Love, w. (1983). The Jenkins Act1vity Survey: Does $1 t$ 
measure peychopathology? Journal of Peychogomet1c Reeerah, 27. 321-325.

Wallaton, B. S., Walloton, K. A., Kaplan, G. D., a Maldes. s. A. (1976). Development and validation of the Health Locus of Control Scale. Journal of Congulting and Clinical Paycholory, 44, 580-585. Waters, W. E. and O'Connor. P. J. (1971). Epldemtology of headache in women. Journal of Neurology, Neurosurgery, and Payantatry. 34. $148-153$

Watkins, P. L. (1986). Behavioral asaessment of Interpersonal akill amons Type $A$ and $B$ college students. Unpublished doctoral disgertation. Wetkins, P. L. \& E1sier, R. M. (1986, March). Behaviorel assessment of interpersonal skill among: Type A and B collere etudents. Paper presented at the annual meetine of the society of Behavioral Medicine, San Francisco.

Watson. D. \& Friend. R. (1969). Measurement of social-evaluative anxiety. Journal of Congulting and Clinical Paycholory. 33. 448-457.

Weldner, G. \& Matthews, K. A. (1978). Reported physical eymptoms ellatted by unpredictable events and the Type A coronary-prone behavior pattern. Journal of Pergonality and soctal Psychology. 36 . 1213-1220.

W1lliams, R. B. (1975). Phygiologic mechantams underlying the association between psychosocial 
and coronary heart disease. In W.D. Gentry \& R.B. Williams (Eds.), Paycholocial aspects of myocardial infarotion and coronary care. st. Loula: C.V. Mosby, 37-50. W1111ams, R. B., Frledman, M., Glass, D. C., Herd, J. A., \& Schnelderman. (1978). Section Bummary: Methods of linklng behavioral and pathophysiological processes. In T.M. Dembrosk1, S.M. WelsB, J.L. Shlelda, S.G. Haynes, M. Feinlelb (Eds.). Coronary-prone behavior. New York: Springer-Verlag, $120-128$.

W1 lliamson. D. A. (1981). Behavioral treatment of migraine and muscie contraction headaches: outcome and theoretical explanations. Prorress in Behav1or Modif1cation, ㄹ. 163-201.

Wolff, H. G. (1963). Headache and other Head Pain. London: Oxpord UnIversity Prese.

Woods. P. J.. Morgan, B. T.. Day, B. W., Jefferson, T.. and Harris, C. (1984). Findings on a relationship between Type $A$ behavior and headaches. Journal of Beheviorel Medic1ne. $I$. 277-286.

Zyzansk1. S, J. \& Jenkins, C. D. (1970). Basic dimeneions within the coronary prone behavior pattern. Journal of Chronta D1seeses. 22. $781-795$ Zyzansk1, S. J., Jenk1ns, C. D., Ryan, T. J., Flessas, A.. E Everlat, M. (1976). Paychologleal 
coronary anglographic findings. Archtves of

Internal Med1a1ne, 136, 1234-1237. 
TABP and Headache

\section{Appendices}


Headache intensity rating $(1-10)$ with anchors/adjectives.

\begin{tabular}{ll} 
Rating & Descriptor \\
\hline 1 & Just Noticeable \\
2 & Weak \\
3 & Mild \\
4 & Uncomfortable \\
5 & Strong \\
6 & Intense \\
7 & Severe \\
8 & Very intense \\
9 & Intolerable \\
10 & Excruciating \\
\hline
\end{tabular}




\section{PLEAse NOTE:}

Copyrighted materials in this document have not been filmed at the request of the author. They are available for consultation, however, in the author's university library.

\section{These consist of pages:}

\begin{tabular}{ll} 
Assertion Inventory & $118-179$ \\
\hline Fear of Negative Evaluation Scale & $121-$ \\
\hline IBI & $123-124$ \\
\hline Illness Behavior Questionnaire & $125-126$ \\
\hline Social Avoidance and Distress Scale & $128-129$ \\
\hline
\end{tabular}

\section{University Mic rofilms International}


Subject :

Dace :

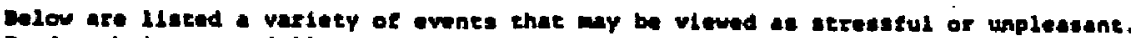

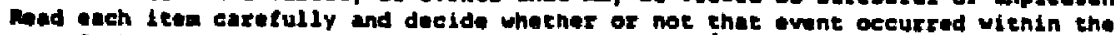
pase 24 hours. If the event did not oecur. place en $-x$ - In the spese maxe to that

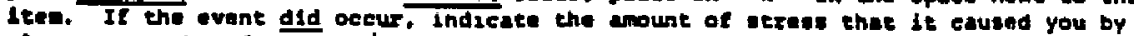

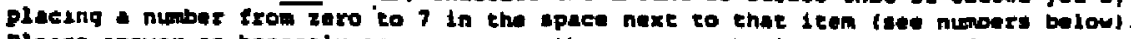
please answer as honesty at you cen so thut we wy obtein accurate informaton.

X - Ald not occur (past 24 hrs.)

2 - occurred but ual not etregsevi

2 - caused ver litede streas

1. Performed poorly at taik

2. Performed poorly due to others

3. moughe about unfinished work

4. Hurrief to moet deadilne

5. Interrupted during task activity

6. Somone spolled your coapleted tank

7. bid somening you are unakitled at

a. Unable to couplete a tak

9. Wel unorganizod

10. Citiclaed or verbally attacked

11. Imored by ochers

12. Spoice or pertoreed in publle

13. Dalt with rude water/ Matresso/sialesprson

14. Intezrupted while talking

15. Whe torced to socialize

16. Sotwone broke a promise/ apposnement

17. Compated with somene

19. Whe stared at

19. Did nat hedr 6 rom semeone you expected to hear from

20. Exferienced unwanted physteal contuct (crowded, pushod)

21. Wes misunderseood

22. Wat moverresed

23. Had your sloep disturbed

24. Forgot Jconthing

25. Pearad 11/nese/preqnaney

26. Dxperienced illnesw/physical discomtore

27. Someone borrowed semething viehoue your parmiseson.

20. Tour property was danaqed

29. Had minor aceldune lbroke gonothing. core clothing

30. Thought about the tuture

31. Ran out of lood/persional . arezele

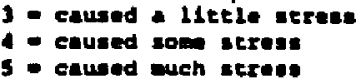

32. Mrqued with spouse/boyt rsend/ girifriand

33. Arqued with another person

34. Hated longer than you wanted

33. Interrupted wale eniniking/ relaxinq

16. Sowton "cut" ahead of you in $11 \pi$

37. Partormed poorly at aport/game

36. Did somening that you did not want to do

39. Unable to conplate all plans lor today

40. Had car erouble

11. Had difficulty in tratele

42. Money problen

43. store lakked a desired lten

44. Mispleced something

45. Aad veather

16. Unaxpeced expenses telneg. tratfle ticket. tec.l

47. Had confrontation with an uthority tiqure

48. Heard som bad nowe

50. Exposed to geared situation or objece

51. Expased to upseteting $T H$ how. covite, book

52. "Pet paeve" vlolated lsomone Fails to knock, etec.

53. Falled to underseand something

54. Worried about another's pronlem

35. Experienced natron eicape tron danger.

56. Stopped unumted personal habit (overtacing, smoking, naslbiting)

37. Had problem vith kid(s)

5a. Has late for work/apposntenent

Any stressors thet aisged? (11st bolow 59.

60. 
EIC

For eech statenent below circle the number which indicates how much you either agree or disagree with it. Use the following scale:

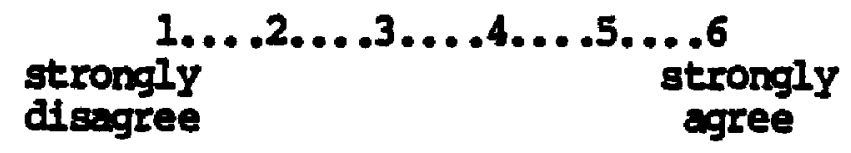

1. If I take care of myself, I can avoid illness

$\begin{array}{llllll}1 & 2 & 3 & 4 & 5 & 6\end{array}$

2. Thenever I get sick, it is because of $1122 \quad 3 \quad 4 \quad 5 \quad 6$ something I've done or not done

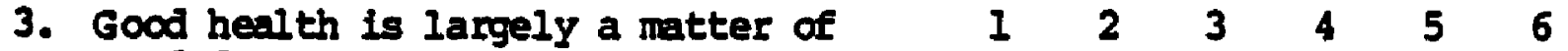
god for tune

4. No matter what I do, If I an going to $1 \quad \begin{array}{llllll}2 & 3 & 4 & 5 & 6\end{array}$ get sick I will get sick

5. Host people do not realize the extent $\begin{array}{llllllll}1 & 2 & 3 & 4 & 5 & 6\end{array}$ to which their illnesses are controlled by accidental happenings

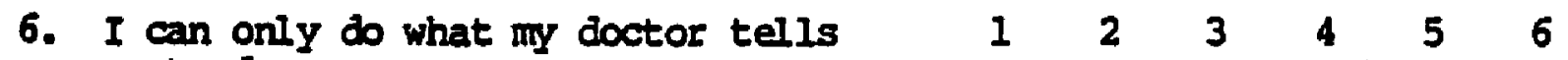
Ine to do

7. There are so many strange diseases $\quad \begin{array}{lllllll} & 2 & 3 & 4 & 5 & 6\end{array}$ around that you can never know how or when you might pick one up

8. When I feel ill, I know it because I $\quad 1 \quad 2 \quad 3 \quad 4 \quad 5 \quad 6$ have not been getting the proper exercise or eating right

9. People who never get sick are just $\quad \begin{array}{lllllll}1 & 2 & 3 & 4 & 5 & 6\end{array}$ plain Iucky

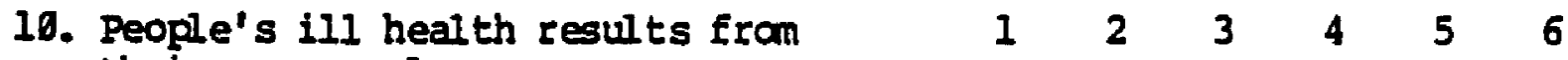
their own carelessness

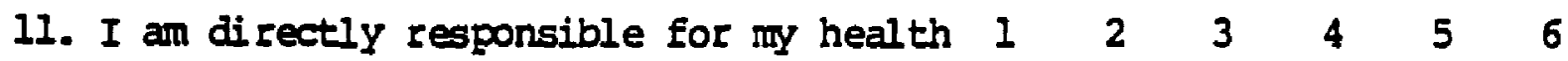




\section{Self-Evaluation Questionnaire}

Directions: A number of statements which people have used to cescribe thenselves are given below. Read each statenent and then rate how you generally feel on the 1 to 4 rating scale below. There are no right or wrong answers.

1. I feel pleasant almost never

2. I tire quickly $\begin{array}{llll}1 & 2 & 3 & 4\end{array}$

3. I feel like crying $\begin{array}{llll}1 & 2 & 3 & 4\end{array}$

4. I wish I could be as happy as others

$\begin{array}{llll}1 & 2 & 3 & 4\end{array}$

5. I am losing out on things because I can't make up my mind soon enough

$\begin{array}{llll}1 & 2 & 3 & 4\end{array}$

6. I fiel rested

1234 .

7. I am "calm, cool, and collected"

$\begin{array}{llll}1 & 2 & 3 & 4\end{array}$

8. I feel that difficulties are piling up so that I cannot overcome them

$\begin{array}{llll}1 & 2 & 3 & 4\end{array}$

9. I wory too much over something that really doesn't matter

10. I an happy

11. I am inclined to take things hard

12. I lack self-confidence

13. I feel secure

14. I try to avoid facing a crisis or difficulty

15. I feel blue

$\begin{array}{llll}1 & 2 & 3 & 4\end{array}$

16. I am content

$\begin{array}{llll}1 & 2 & 3 & 4\end{array}$

$\begin{array}{llll}1 & 2 & 3 & 4\end{array}$

$\begin{array}{llll}1 & 2 & 3 & 4\end{array}$

$\begin{array}{llll}1 & 2 & 3 & 4\end{array}$

$\begin{array}{llll}1 & 2 & 3 & 4\end{array}$

$\begin{array}{llll}1 & 2 & 3 & 4\end{array}$

17. Some unimportant thought cuns through my mind and bothers me

$\begin{array}{llll}1 & 2 & 3 & 4\end{array}$

18. I take disappointments so keenly that I cannot put them out of my mind

$\begin{array}{llll}1 & 2 & 3 & 4\end{array}$

19. I am a steady person

$\begin{array}{llll}1 & 2 & 3 & 4\end{array}$

$\begin{array}{llll}1 & 2 & 3 & 4\end{array}$

20. I get in a state of tension or turmoil as I think over my recent concems and interests 
TABP and Headache 130

Table 24

Group means for ABsertion Inventory-RP $(n=46)$.

\section{Headache D1arnos18}

Migraine Muscle Contraction

JAS Group

$\begin{array}{llll}\text { A } & 99.36 & 102.71 & 101.04 \\ \times & 113.67 & 107.64 & 110.65 \\ \text { B } & 105.50 & 111.29 & 108.39 \\ & 106.18 & 107.21 & \end{array}$




\section{Table 25}

Group means for Assertion Inventory-DD $(n=46)$.

\section{Headache D1arnosis}

Migraine Musle Contraction

JAS GrouP

$\begin{array}{rrrr}\text { A } & 88.18 & 94.57 & 91.38 \\ \times & 104.67 & 88.55 & 96.61 \\ \text { B } & 77.75 & 109.14 & \\ & 90.20 & 97.42 & 93.45\end{array}$


TABP and Headache 132

Table 26

Group meane for DSI-Frequency $(n=49)$.

Headache DIernosis

Migraine Muscle Contraction

JAS Group

$\begin{array}{llll}\text { A } & 12.58 & 11.07 & 11.83 \\ \times & 11.81 & 10.74 & 11.28 \\ \text { B } & 9.28 & 14.82 & 12.05\end{array}$

11.23

12.21 
Table 27

Group means for DSI-Sum $(n=49)$.

Headeche D1arnog1B

Migraine Muscie Contraction

JAS Group

$\begin{array}{llll}\mathbf{A} & 33.24 & 26.92 & 30.20 \\ \mathrm{X} & 32.49 & 27.22 & 29.85 \\ \mathrm{~B} & 23.12 & 24.22 & 23.67 \\ 29.70 & 26.12 & \end{array}$


TABP and Headache 134

Table 28

Group meene for FNE (n $=57)$.

\section{Headeche Diarnosia}

Migraine

Muscle Contraction

\section{JAS Group}

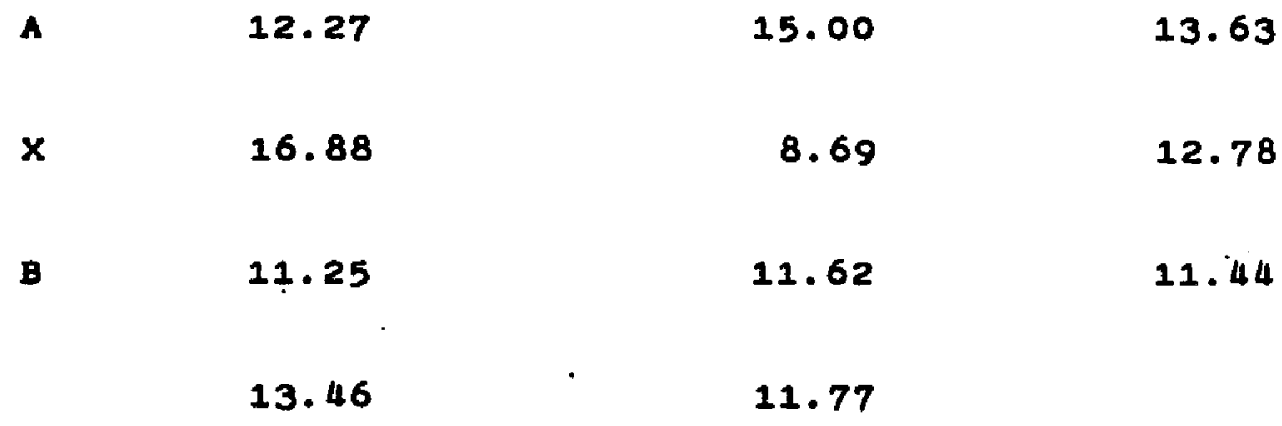


TABP and Headeche 135

Tabie 29

Group meane for HAF $(n=60)$

\section{Headeche D1arnog1日}

Migraine Muscle Contraction

JAS Group

$\begin{array}{llll}\text { A } & 13.06 & 24.71 & 18.89 \\ \times & 9.89 & 17.92 & 13.91 \\ \text { B } & 14.20 & 20.00 & 17.10 \\ & 12.38 & 20.88 & \end{array}$


TABP and Headeche 136

Table 30

Group means for hAI (n=60)

\author{
Headache Diarnosig \\ Mieraine Muscle Contraction
}

JAS Group

$\begin{array}{llll}\text { A } & 4.25 & 3.57 & 3.91 \\ \times & 4.24 & 3.89 & 4.07 \\ \text { B } & 2.94 & 3.25 & 3.09\end{array}$

3.81

3. 57 
TABP and Headache 137

Table 31

Group means for HLC $(n=56)$

Headache DLarnosis

Miralne Muscle Contraction

JAS Group

$\begin{array}{llll}\text { A } & 32.73 & 39.29 & 36.01 \\ \times & 36.71 & 34.54 & 35.13 \\ \text { B } & 39.50 & 35.90 & 37.70 \\ & 35.98 & 36.57 & \end{array}$


TABP and Headache 138

Table 32

Group means for IBI $(n=59)$.

\section{Headache Diarnosis}

Misratne

Muscle Contraction

JAS Group

A

58. 37

52.57

55.47

x

74.12

58.15

66.14

$\mathbf{B}$

80.40

64.60

72.50

70.97

58.44 
Table 33

Group means for IBQ scales $(n=54)$.

Group

Illness Behavior Questionnaire Scale

\begin{tabular}{lrrrr}
\hline & 2 & 3 & 7 & WI \\
\hline MG & 2.43 & 1.17 & 2.01 & 3.93 \\
MC & 1.92 & 1.14 & 1.67 & 3.69 \\
Type A & 1.64 & 1.60 & 2.07 & 2.58 \\
Type X & 2.63 & 1.12 & 1.83 & 4.73 \\
Type B & 2.25 & .75 & 1.62 & 4.13 \\
MG-A & 1.79 & 1.86 & 2.14 & 3.00 \\
MG-X & 3.00 & .90 & 1.90 & 5.80 \\
MG-B & 2.50 & .75 & 2.00 & 3.00 \\
MC-A & 1.50 & 1.33 & 2.00 & 2.17 \\
MC-X & 2.25 & 1.33 & 1.75 & 3.67 \\
MC-B & 2.00 & .75 & 1.25 & 5.25 \\
& & & & \\
\hline
\end{tabular}


Table 34

Group means for MMPI scales $(n=54)$.

Group

MMPI Scaje

\begin{tabular}{|c|c|c|c|c|c|c|c|c|c|c|}
\hline & $\mathbf{L}$ & $\mathbf{F}$ & $k$ & 1 & 2 & 3 & 4 & 5 & 6 & 7 \\
\hline$M G$ & 4.49 & 4.42 & 12.46 & 62.10 & 56.14 & 61.12 & 56.26 & 44.03 & 52.40 & 53.47 \\
\hline$M C$ & 4.57 & 4.75 & 13.11 & 65.33 & 61.67 & 64.11 & 56.74 & 53.23 & 55.66 & 59.93 \\
\hline Type A & 4.27 & 4.91 & 12.90 & 58.23 & 55.74 & 58.64 & 54.87 & 50.60 & 55.26 & 55.53 \\
\hline Type $X$ & 3.93 & 5.33 & 11.60 & 69.41 & 63.41 & 66.27 & 60.45 & 45.48 & 56.52 & $62: 02$ \\
\hline Type B & 5.38 & 3.50 & 14.06 & 63.50 & 57.56 & 62.94 & 54.19 & 49.81 & 50.31 & 52.56 \\
\hline MG-A & 5.50 & 4.00 & 15.00 & 60.50 & 53.75 & 61.50 & 57.00 & 45.25 & 47.75 & 49.00 \\
\hline$M G-X$ & 4.13 & 5.00 & 10.12 & 68.62 & 59.75 & 62.87 & 58.62 & 41.50 & 54.37 & 57.50 \\
\hline$M G-B$ & 3.83 & 4.25 & 12.25 & 57.17 & 54.92 & 59.00 & 53.17 & 45.33 & 55.08 & 53.92 \\
\hline$M C-A$ & 5.25 & 3.00 & 13.12 & 66.50 & 61.37 & 64.37 & 51.37 & 54.37 & 52.87 & 56.12 \\
\hline$M C-X$ & 3.73 & 5.67 & 13.07 & 70.20 & 67.07 & 69.97 & 62.27 & 49.47 & 58.67 & 66.53 \\
\hline$M C-B$ & 4.71 & 5.57 & 13.14 & 59.29 & 56.57 & 58.29 & 56.57 & 55.86 & 55.43 & 57.14 \\
\hline
\end{tabular}


Table 34

Group means for MMPI scales $(n=54)$.

Group MMPI Scale

\begin{tabular}{lccc}
\hline & 8 & 9 & 0 \\
\hline MG & 53.07 & 56.28 & 57.99 \\
MC & 56.91 & 54.66 & 58.38 \\
Type A & 57.27 & 55.97 & 59.88 \\
Type X & 58.38 & 58.31 & 59.79 \\
Type B & 49.31 & 52.12 & 54.87 \\
MG-A & 55.83 & 56.08 & 60.33 \\
MG-X & 54.62 & 58.75 & 61.37 \\
MG-B & 48.75 & 54.00 & 52.25 \\
MC-A & 58.71 & 55.86 & 59.43 \\
MC-X & 62.13 & 57.87 & 58.20 \\
MC-B & 49.87 & 50.25 & 57.50 \\
& & & \\
\hline
\end{tabular}


TABP and Headache 142

Table 35
Group meane for SAD $(n-57)$.

Headeche D1ernosis

Migraine Muacle Contraction

JAS Group

$\begin{array}{rrrr}\text { A } & 10.87 & 8.25 & 9.56 \\ \times & 12.12 & 5.92 & 9.02 \\ \text { B } & 2.75 & 13.12 & 7.94 \\ & 8.58 & 9.10 & \end{array}$


Table 36

Group mane for STAI $(n=60)$

\section{Headeche D1ernos18}

Mieralne Muscle contraction

\section{JAS Group}

A

$\mathbf{x}$

B

44.19

43.44

32.80

40.14
43.14

43.67

43. 77

43.20

38.00

43. 37 
TABP and Headache 144

Table 37

Grour means for zung $(n-60)$

Headache D1arnosis

Migraine Muscle Contrection

JAS Group

$\mathbf{A}$

$\mathbf{x}$

B
38.31

37.33

33.40

36.35
36.43

38.77

36.70

$37 \cdot 30$
37.37

38.05

35.05 


\section{CURRICULUM VITAE}

Ne11 B. Rappaport, Ph.D.

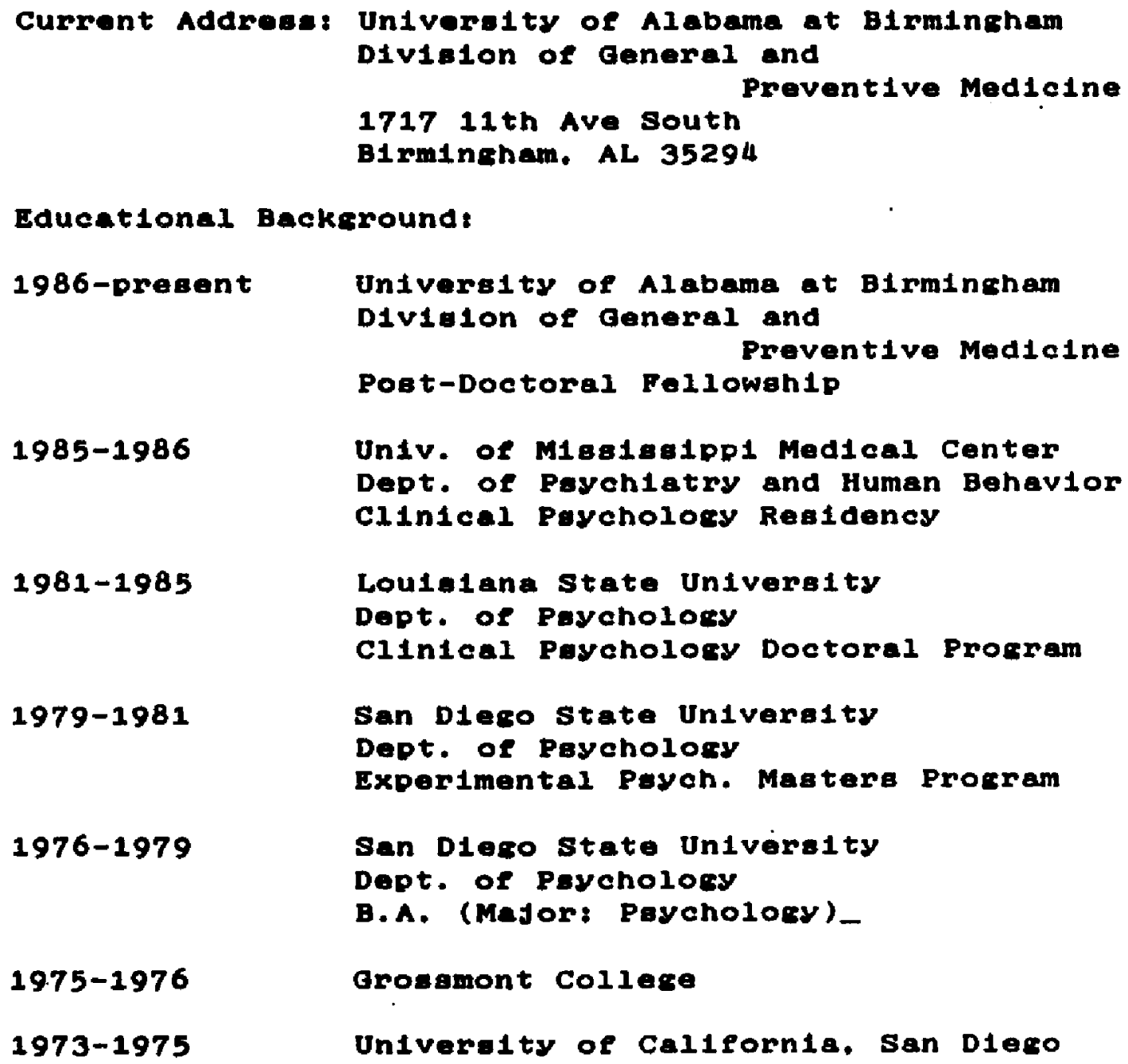

Profesional Memberships:

Aseociation for the Advancement of Pascholory Amerlcan Paychologlcal Association Association for the Advancement of Behavior Therapy Southeastern Paycholorical Areociation

\section{Publications:}

Brantley, P. J.. Wagsoner, C. D., Jonea, G. N., \& Rappaport, N. B. (In press). A delly etress Inventory: Development, rellability, and validity. Journal of Behavioral Medicine. 
Rappaport, N. B., McAnulty, D. P., Wargoner, C. D., Brantley, P. J. (In press). Cluater enalysis of MMPI profllea in ehronte headeche population. Journel of Behevioral Medicine.

Dubbert, P. M. Rappeport, N. B., \& Martin, J. E. (In prese). Exerclse in cardlovascular disease. Behavior Modifleation.

Osborne, Y. H., H1nz, L. D., Rappaport, N. B. . W1lliams, H. S., \& Tuma, J. T. (In press). Sociel attractivenese, temperament, and socloeconomic status as predictors of tendency to report child abuse. Journel of Soclel and Clinteal Paycholory.

Oaborne, Y. H. Rappaport, N. B., \& Meyer, R. (In press). The role of persuasion in aentencine severity with mock Jurors. Behavioral Sciences and the Law.

W1111ams, H. S., Osborne, Y. H., \& Rappaport, N. B. (in press). Child abuse reporting laws: Differences among profesetonal sroups. In knowledge and compliance. The southern Paycholorist.

Calion, E. B., Brantiey, P. J., MeAnulty, D. P. . Wackoner, C. D.. Rappaport, N. B., JoneB, G. N.. Goreczny, A. (1986). The effect of muscle contraction headache chronicity on frontal EMG. Headache, 26. 356-359.

MoAnulty, D. P., Rappaport, N. B., Wargoner, C. D. . Brantley, P. J.. Barkemeyer, C. \& Mckenzie, S. J. (1986). Psychopathology in voluteers for headache research: Early vo. later respondents. Headache, 26, 37-38

McAnulty, D. P., Rappaport. N. B., \& Mcanulty, R. D. (1985). An a posteriori investigation of the standard MMPI valialty scales. Paycholorical Resporta. 57. 95-98.

Osborne. Y. H. 8 Rappaport, N. B. (1985). Influence of Berlousness of charce, defendant's race and SES, and Juror characteristics in sentencins severity. Behavioral Sciences and the Law.

Rappaport, N. B., \& McAnulty, D. P. (1985). The effect of accented speech on the scorling of ambleuoug WISC-R responees by prejudice and non-prejudice raters. Journal of Psychoeducational Assessment. 3. $275-283$. 
Candidate: Neil B. Rappaport

Major Field: Psychology

Title of Dissertation: An Exploration of the Type a Behavior Pattern In Chronic Headache Sufferers

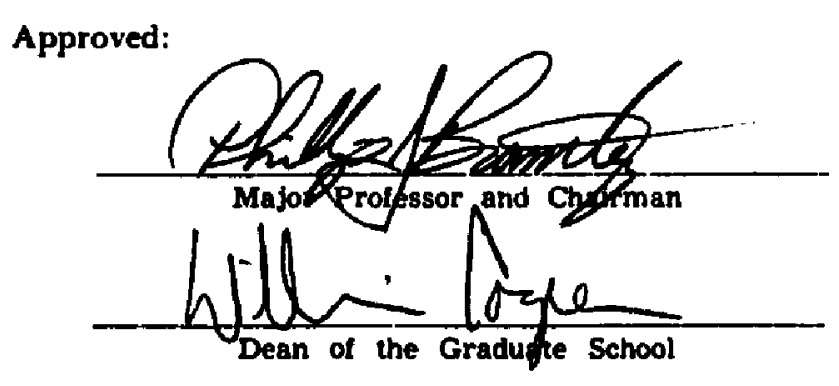

EXAMINING COMMITTEE:

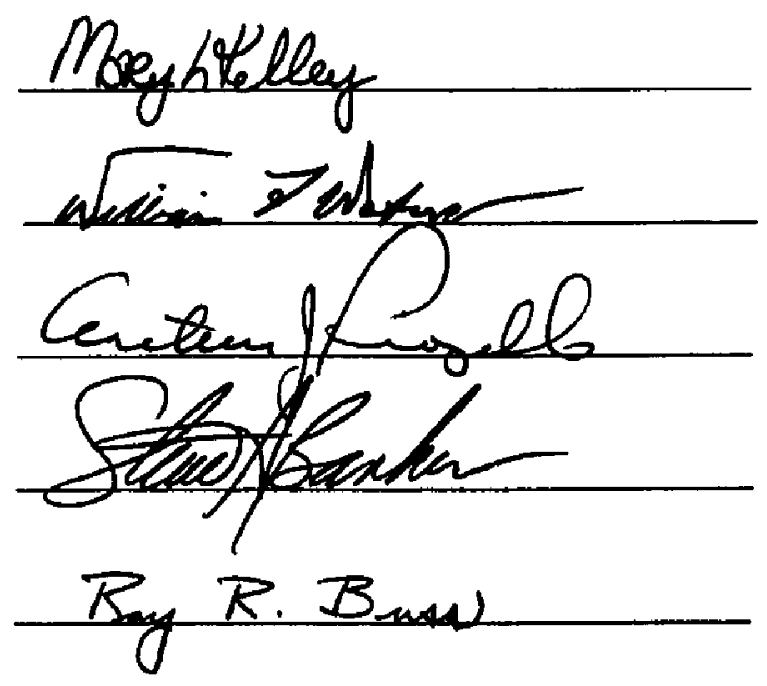

Date of Examination: 